\title{
Novel insights into early life stages of finned octopods (Octopoda: Cirrata)
}

\author{
Alexander Ziegler ${ }^{1 *}$ (D), Abigail Miller ${ }^{1}$ and Nina Nagelmann²
}

\begin{abstract}
The finned or dumbo octopods (Octopoda: Cirrata) constitute a cephalopod (Mollusca: Cephalopoda) taxon almost exclusively comprising organisms that inhabit the deep-sea. This renders studying the general biology of adult cirrate specimens a difficult task, but even more so when it comes to gathering knowledge on their early life stages. During his comprehensive research exploits on cephalopod development, the late Sigurd von Boletzky (1942-2020) also sought to shed light on specific adaptations that eggs and embryos of these enigmatic deep-sea octopods might show. Based on his seminal work, the present article sets out to provide additional data on a broad range of early cirrate life stages, including egg capsules without any obvious embryonic stage as well as those containing embryos. These previously unreported specimens obtained from museum collections were analyzed using conventional morphological as well as modern three-dimensional imaging techniques. The present overview includes specimens from four of the five oceans, i.e., the Atlantic, Pacific, Indian, and Southern Ocean. Based on information on cirrate ovum, chorion, and egg capsule size as well as shape gathered from the literature, an attempt is made here for the first time to identify von Boletzky's as well as the specimens introduced here down to at least genus level. The combined data provide novel insights into early life stages of finned octopods, aiming to continue von Boletzky's legacy with regard to developmental research on a still largely enigmatic taxon of extant deep-sea cephalopods.
\end{abstract}

Keywords: Development, Deep-sea, Dumbo, Magnetic resonance imaging, Micro-computed tomography, Egg, Ovum, Chorion, Capsule, Embryo, Hatchling

"Pour le moment, le développement des Cirrata répresente encore une des plus grandes lacunes dans nos connaissances sur les Céphalopodes vivants." (Boletzky 1978-1979: 112).

\section{Introduction}

In his comprehensive body of work on cephalopod (Mollusca: Cephalopoda) development, the late Dr. Sigurd von Boletzky (1942-2020) occasionally touched on a group of rare deep-sea organisms, the finned or dumbo octopods (Octopoda: Cirrata). These still relatively enigmatic

\section{Editorial handling: Christian Klug.}

*Correspondence: aziegler@evolution.uni-bonn.de

1 Institut für Evolutionsbiologie und Ökologie, Rheinische Friedrich-

Wilhelms-Universität, An der Immenburg 1,53121 Bonn, Germany

Full list of author information is available at the end of the article cephalopods are sister to the much better-known finless octopods, the Incirrata (e.g., Collins \& Villanueva, 2006; Pardo-Gandarillas et al., 2021; Piertney et al., 2003; Ziegler \& Sagorny, 2021), whose early life stages have been studied extensively for more than a century using several well-known and easily accessible species (Boletzky, 1998, 2003, 2009). Unfortunately, in contrast to the predominantly shallow water-inhabiting incirrate octopods, their cirrate brethren are much more difficult to come by, in particular in the form of material suitable for developmental studies (Collins \& Villanueva, 2006). However, deep-sea trawling activities occasionally result in cirrate egg capsules being brought to the surface and it was while studying such material that von Boletzky found that some of these egg capsules contained embryos that would permit generalized inferences on cirrate development (Boletzky, 1978-1979, 1980, 1982, 1985). 
In contrast to incirrates, dumbo octopods lay single eggs with a tough outer capsule (Boletzky, 1998) that forms as a result of the egg composed of fertilized ovum and chorion being coated in a sticky substance whilst passing through the large, bipartite oviducal gland located almost at the end of the female reproductive tract (Aldred et al., 1983; Meyer, 1906). This sticky coating hardens after several minutes when exposed to seawater (Vecchione et al., 1998) and in some-if not all-cases acts as an initially elastic cement that helps to attach the egg capsule to a hard substrate on the ocean floor (Collins \& Villanueva, 2006). In general, hard egg capsules are typical of benthic and benthopelagic cephalopods that lay single or multiple, relatively large eggs at great depths or at high latitudes (Boletzky, 1986). As a response to this extreme habitat, estimates of the duration of embryonic development in cirrates suggest development times of one to at least 3 years (Laptikhovsky, 1999; Nesis, 1999). While it remains unclear at present how cirrate embryos hatch precisely, physical mechanisms are presumably required to penetrate the protective egg capsule (Shea et al., 2018). However, so far no sign of Kölliker's or Hoyle's organ has been found in cirrate embryos (Boletzky, 1978-1979, Shea et al., 2018). Since his seminal article describing six cirrate egg capsules that contained well-developed embryos (Boletzky, 1982), von Boletzky methodologically aimed at placing his findings within a larger conceptual framework on cephalopod development which he had built over the course of his scientific exploits (Boletzky, 2002, 2003, 2006, 2009, 2010, 2012). But, he also cautioned that it would not be possible to draw direct embryological conclusions from these six specimens as they were likely to represent at least five different cirrate species (Boletzky, 1982).

In light of novel cirrate material becoming accessible from scientific deep-sea cruises as well as the availability of new analytical techniques that permit studying rare specimens in a non-destructive fashion (Xavier et al., 2015; Ziegler et al., 2018), the principle aims of the present study are to provide an overview of previous research conducted on early cirrate life stages and to demonstrate the potential of novel methods for studying such specimens. Based on these two keystones, a first attempt is here made to identify a diverse array of early cirrate life stage specimens down to at least genus level to provide a solid foundation for drawing embryological conclusions in cirrates as envisoned several decades ago by the late Dr. Sigurd von Boletzky.

\section{Materials and methods}

\section{Specimens}

The six cirrate specimens described and figured by Boletzky (1978-1979, 1980, 1982, 1985) serve as the main reference point for all subsequently acquired data and are thus integrated here (Table $1 \mathrm{~A}-\mathrm{F}$ ). In the course of the present study, previously unreported specimens (Table 1G-L, N, O) were obtained from the collections of the National Institute of Water and Atmospheric Research (NIWA) and the Santa Barbara Museum of Natural History (SBMNH). This fixed material was first photographed using an EOS 600D digital camera (Canon Inc., Tokyo, Japan) mounted on a Stemi 2000 stereomicroscope (Zeiss, Oberkochen, Germany)-note that all descriptions of specimen color are based on fixed material. Following photography, two-dimensional (2D) $\mathrm{X}$-ray imagery was gathered using a SkyScan $1272 \mu \mathrm{CT}$ system (Bruker MicroCT, Kontich, Belgium) to determine, which of these specimens would be suitable for subsequent three-dimensional (3D) magnetic resonance imaging (MRI) or micro-computed tomography $(\mu \mathrm{CT})$. In addition, the present study incorporates photographic imagery of an unvouchered specimen collected in the Angola Basin (Table 1M) as well as of a specimen deposited at the United States National Museum (USNM) obtained on the Corner Rise Seamounts (Table 1P). Further data recently gathered using a specimen from the USNM collections was additionally incorporated into this study (Table 1Q). Finally, the specimen list also includes descriptions of unvouchered cirrate specimens collected in the northwestern Atlantic Ocean almost 150 years ago (Table 1R). Measurements were carried out according to previously published guidelines (Roper \& Voss, 1983; Voss \& Pearcy, 1990).

\section{Magnetic resonance imaging}

Three egg capsules and one prematurely hatched individual were analyzed in 3D using MRI (Table 1I-K, P). Prior to scanning, the ethanol-preserved specimens were immersed in distilled water for a few hours (Ziegler \& Mueller, 2011; Ziegler et al., 2011). Scanning was conducted using a horizontal 9.4 $\mathrm{T}$ BioSpec 94/20 preclinical MRI system equipped with a CryoProbe transmit-receive surface resonator (Bruker BioSpin $\mathrm{GmbH}$, Ettlingen, Germany). This scanner uses a $1 \mathrm{~T} / \mathrm{m}$ gradient system and the specimen containers were placed inside a $35 \mathrm{~mm}$ volume coil for imaging. Scan parameters for the three egg capsules were: 3D FLASH MR sequence, $35 \mathrm{~ms}$ repetition time, $5 \mathrm{~ms}$ echo time, $10^{\circ}$ flip angle, 4 averages, $2 \mathrm{~h} 32 \mathrm{~min}$ acquisition time, and $51 \mu \mathrm{m}$ isotropic voxel resolution. For the single hatchling, the scan parameters were: 3D tRARE MR sequence, $1500 \mathrm{~ms}$ repetition time, $11.226 \mathrm{~ms}$ echo time, $44.91 \mathrm{~ms}$ effective echo time, 8 averages, RARE factor 14, $11 \mathrm{~h} 56 \mathrm{~min} 48 \mathrm{~s}$ acquisition time, and $58 \mu \mathrm{m}$ isotropic voxel resolution. The resulting raw data were reconstructed using the software ParaVision 5.1 (Bruker BioSpin GmbH). 
Table 1 List of early cirrate life stage specimens incorporated into the present study

\begin{tabular}{|c|c|c|c|c|}
\hline Specimen & Cruise & Locality & Documentation & Source \\
\hline A & $\begin{array}{l}\text { BIOGAS 5, Station CV40, R/N } \\
\text { Cryos, } 1974\end{array}$ & $\begin{array}{l}\text { Meriadzec Terrace, North Atlantic } \\
\text { Ocean, } 47^{\circ} 33^{\prime} \mathrm{N} 09^{\circ} 01^{\prime} \mathrm{W}, 2860 \mathrm{~m}\end{array}$ & Photography & Boletzky $(1980,1982,1985)$ \\
\hline B & $\begin{array}{l}\text { BIOGAS 6, Station DS81, R/V Jean } \\
\text { Charcot, } 1974\end{array}$ & $\begin{array}{l}\text { Biscay Abyssal Plain, North } \\
\text { Atlantic Ocean, } 46^{\circ} 28^{\prime} \mathrm{N} 10^{\circ} 24^{\prime} \mathrm{W} \text {, } \\
4715 \mathrm{~m}\end{array}$ & Photography, illustration & $\begin{array}{l}\text { Boletzky (1978-1979, 1980, 1982, } \\
\text { 1985) }\end{array}$ \\
\hline C & $\begin{array}{l}\text { GALATHEA II, Station 279, R/V } \\
\text { Galathea, 1950-1952 }\end{array}$ & $\begin{array}{l}\text { Laccadive Sea, Indian Ocean, } \\
01^{\circ} 00^{\prime} \mathrm{N} 76^{\circ} 17^{\prime} \mathrm{E}, 4425 \mathrm{~m}\end{array}$ & Illustration & Boletzky $(1980,1982)$ \\
\hline D & $\begin{array}{l}\text { GALATHEA II, Station 663, RN } \\
\text { Galathea, 1950-1952 }\end{array}$ & $\begin{array}{l}\text { Hikurangi Plateau, South Pacific } \\
\text { Ocean, } 36^{\circ} 31^{\prime} \mathrm{S} 178^{\circ} 38^{\prime} \mathrm{W}, \\
4520 \mathrm{~m}\end{array}$ & Illustration & Boletzky $(1980,1982)$ \\
\hline $\mathrm{E}$ & $\begin{array}{l}\text { GALATHEA II, Station 664, R/N } \\
\text { Galathea, 1950-1952 }\end{array}$ & $\begin{array}{l}\text { Hikurangi Plateau, South Pacific } \\
\text { Ocean, } 36^{\circ} 34^{\prime} \mathrm{S} 178^{\circ} 57^{\prime} \mathrm{W} \text {, } \\
4625 \mathrm{~m}\end{array}$ & Illustration & Boletzky $(1980,1982)$ \\
\hline $\mathrm{F}$ & $\begin{array}{l}\text { MD04/BENTHOS, Station CP243, } \\
\text { RN Marion-Dufresne, } 1975\end{array}$ & $\begin{array}{l}\text { Kerguelen Plateau, Indian Ocean, } \\
46^{\circ} 47.7^{\prime} \mathrm{S} 70^{\circ} 30.2^{\prime} \mathrm{E}, 1218 \mathrm{~m}\end{array}$ & Illustration & Boletzky $(1980,1982)$ \\
\hline G & $\begin{array}{l}\text { Gilbert Van Dykhuizen Collec- } \\
\text { tion, } 1992\end{array}$ & $\begin{array}{l}\text { Monterey Canyon, North } \\
\text { Pacific Ocean, 36 } 46^{\prime} 59.84^{\prime \prime} \mathrm{N} \\
121^{\circ} 50^{\prime} 3.83^{\prime \prime} \mathrm{W}, 200-400 \mathrm{~m}\end{array}$ & $\begin{array}{l}\text { Photography, illustration } \\
\text { (SBMNH 142130) }\end{array}$ & $\begin{array}{l}\text { Ziegler and Miller (2022d), this } \\
\text { study }\end{array}$ \\
\hline $\mathrm{H}$ & $\begin{array}{l}\text { Oregon State University Cruise } \\
\text { Y7210A, Station BMT haul 306, } \\
\text { R/V Yaquina, } 1972\end{array}$ & $\begin{array}{l}\text { Tufts Abyssal Plain, North Pacific } \\
\text { Ocean, } 45^{\circ} 02.0^{\prime} \mathrm{N} 134^{\circ} 42.2^{\prime} \mathrm{W}, \\
3900 \mathrm{~m}\end{array}$ & Photography (SBMNH 618597) & $\begin{array}{l}\text { Ziegler and Miller (2022b), this } \\
\text { study }\end{array}$ \\
\hline । & $\begin{array}{l}\text { NIWA TAN0803, Station 082, R/V } \\
\text { Tangaroa, } 2008\end{array}$ & $\begin{array}{l}\text { Macquarie Ridge Complex, } \\
\text { South Pacific Ocean, } 53^{\circ} 43^{\prime} 44.4^{\prime \prime S} \\
159^{\circ} 09^{\prime} 46.8^{\prime \prime E} \text {, 1087-1160 m }\end{array}$ & Photography, MRI (NIWA 40590) & This study \\
\hline J & $\begin{array}{l}\text { NIWA TAN0803, Station 118, R/N } \\
\text { Tangaroa, } 2008\end{array}$ & $\begin{array}{l}\text { Macquarie Ridge Complex, } \\
\text { South Pacific Ocean, } 59^{\circ} 02^{\prime} 52.8^{\prime \prime S} \\
158^{\circ} 54^{\prime} 03.6^{\prime \prime E} \text {, 1400-1615 m }\end{array}$ & Photography, MRI (NIWA 41 108) & This study \\
\hline K & $\begin{array}{l}\text { NZOI SOP, Station Z-9173, RN } \\
\text { Tangaroa, } 1998\end{array}$ & $\begin{array}{l}\text { Hikurangi Plateau, South } \\
\text { Pacific Ocean, 3702'18.0"S } \\
176^{\circ} 41^{\prime} 54.0^{\prime \prime W}, 1003-1108 \mathrm{~m}\end{array}$ & Photography, MRI (NIWA 83817) & $\begin{array}{l}\text { Ziegler and Miller (2022a), this } \\
\text { study }\end{array}$ \\
\hline L & $\begin{array}{l}\text { NIWA TAN0803, Station 082, R/V } \\
\text { Tangaroa, } 2008\end{array}$ & $\begin{array}{l}\text { Macquarie Ridge Complex, } \\
\text { South Pacific Ocean, } 53^{\circ} 43^{\prime} 44.4^{\prime \prime S} \\
159^{\circ} 09^{\prime} 46.8^{\prime \prime} E, 1087-1160 \mathrm{~m}\end{array}$ & Photography, HCT (NIWA 40590) & This study \\
\hline M & $\begin{array}{l}\text { DIVA-1, Station M48/1-351, RN } \\
\text { Meteor, } 2000\end{array}$ & $\begin{array}{l}\text { Angola Basin, South Atlantic } \\
\text { Ocean, } 16^{\circ} 25.2^{\prime} \mathrm{S} 05^{\circ} 28.2^{\prime} \mathrm{E} \\
5400 \mathrm{~m}\end{array}$ & Photography & Vecchione et al. (2016), this study \\
\hline N & $\begin{array}{l}\text { ANTARKTIS XIII/3, Station 39/13 } \\
\text { GSN 6, R/N Polarstern, } 1996\end{array}$ & $\begin{array}{l}\text { Off Brunt Ice Shelf, Southern } \\
\text { Ocean, } 73^{\circ} 36^{\prime} 18^{\prime \prime} \mathrm{S} 22^{\circ} 19^{\prime} 00^{\prime \prime} \mathrm{W}, \\
620-640 \mathrm{~m}\end{array}$ & $\begin{array}{l}\text { Photography, } \mu C T \text { (SBMNH } \\
\text { 618600) }\end{array}$ & This study \\
\hline O & $\begin{array}{l}\text { ANTARKTIS XIII/3, Station 39/13 } \\
\text { GSN 6, R/N Polarstern, } 1996\end{array}$ & $\begin{array}{l}\text { Off Brunt Ice Shelf, Southern } \\
\text { Ocean, } 73^{\circ} 36^{\prime} 18^{\prime \prime} \mathrm{S} 22^{\circ} 19^{\prime} 00^{\prime \prime} \mathrm{W}, \\
620-640 \mathrm{~m}\end{array}$ & $\begin{array}{l}\text { Photography, } \mu C T \text { (SBMNH } \\
618600 \text { ) }\end{array}$ & This study \\
\hline$P$ & $\begin{array}{l}\text { Deep Atlantic Stepping Stones, } \\
\text { Dive H07, R/ Ronald H. Brown, } \\
2005\end{array}$ & $\begin{array}{l}\text { Corner Rise Seamounts, North } \\
\text { Atlantic Ocean, } 35^{\circ} 23^{\prime} 44.32^{\prime \prime} \mathrm{N} \\
51^{\circ} 16^{\prime} 15.14^{\prime \prime} \mathrm{W}, 2068 \mathrm{~m}\end{array}$ & $\begin{array}{l}\text { Photography, MRI (USNM } \\
\text { 1460906) }\end{array}$ & This study \\
\hline Q & $\begin{array}{l}\text { Deep Atlantic Stepping Stones, } \\
\text { Dive H15, R/V Ronald H. Brown, } \\
2005\end{array}$ & $\begin{array}{l}\text { Kelvin Seamount, North } \\
\text { Atlantic Ocean, } 38^{\circ} 46^{\prime} 14.16^{\prime \prime} \mathrm{N} \\
64^{\circ} 05^{\prime} 41.01^{\prime \prime} \mathrm{W}, 1965 \mathrm{~m}\end{array}$ & $\begin{array}{l}\text { Photography, MRI (USNM } \\
\text { 1460905) }\end{array}$ & $\begin{array}{l}\text { Shea et al. (2018), Ziegler (2018), } \\
\text { this study }\end{array}$ \\
\hline R & $\begin{array}{l}\text { Albatross, Station 2209, R/V } \\
\text { Albatross, } 1884\end{array}$ & $\begin{array}{l}\text { Hudson Canyon, North Atlantic } \\
\text { Ocean, } 39^{\circ} 35^{\prime} 00^{\prime \prime} \mathrm{N} 71^{\circ} 18^{\prime} 45^{\prime \prime} \mathrm{W}, \\
1975 \mathrm{~m}\end{array}$ & Written report & Verrill (1885) \\
\hline
\end{tabular}

\section{Contrast-enhanced micro-computed tomography} A single cirrate egg containing an embryo and subsequently the individual, extracted embryo as well as two larger embryos were analyzed in 3D using contrastenhanced $\mu \mathrm{CT}$ (Table $1 \mathrm{~L}, \mathrm{~N}, \mathrm{O}$ ). Samples were stained for 6 weeks each with $0.3 \%$ phosphotungstic acid (PTA) 
in 70\% ethanol (Ziegler, 2019; Ziegler et al., 2018). To prevent movement artifacts during scanning, specimens were placed inside conical plastic tubes filled with $70 \%$ ethanol. Scanning was conducted using a SkyScan 1272 system with a detector size of $4904 \times 3280$ px (Bruker MicroCT, Kontich, Belgium). Scans were made with $180^{\circ}$ rotation using a $0.25 \mathrm{~mm}$ aluminum filter. For specimen NIWA 40590 (chorion with embryo), the following parameters were used: $60 \mathrm{kV}$ source voltage (VOL), 166 $\mu \mathrm{A}$ source current (CUR), $1114 \mathrm{~ms}$ exposure (EXP), 7 averages (AVE), $0.3^{\circ}$ step size (STE), $7 \mu \mathrm{m}$ isotropic voxel resolution (IVR), $1 \mathrm{~h} 37 \mathrm{~min}$ acquisition time (TA); for specimen NIWA 40590 (extracted embryo with $1 \mathrm{~mm}$ mantle length): $45 \mathrm{kV}$ VOL, $165 \mu \mathrm{A}$ CUR, $1166 \mathrm{~ms}$ EXP, 9 AVG, $0.3^{\circ} \mathrm{STE}, 1.5 \mu \mathrm{m}$ IVR, 2 h 3 min TA; for specimen SBMNH 618600 (embryo with $5 \mathrm{~mm} \mathrm{ML}$ ): $60 \mathrm{kV}$ VOL, $166 \mu \mathrm{A}$ CUR, $1114 \mathrm{~ms}$ EXP, 8 AVG, 0.3 STE, $6 \mu \mathrm{m}$ IVR, 1 h 49 min TA; for specimen SBMNH 618600 (embryo with $10 \mathrm{~mm} \mathrm{ML}$ ): $60 \mathrm{kV}$ VOL, $166 \mu \mathrm{A}$ CUR, $741 \mathrm{~ms}$ EXP, 8 AVG, $0.4^{\circ}$ STE, $9 \mu \mathrm{m}$ IVR, 56 min TA. Reconstruction of the resulting raw data and thermal drift compensation were accomplished using the software NRecon 1.5 (Bruker MicroCT) with parameters set to smoothing $=1$, ring artifact correction $=15$, and beam hardening correction $=20 \%$.

\section{Data set visualization and modeling}

The computer hardware used for 2D virtual sectioning and $3 \mathrm{D}$ visualization was based on a 64-bit operating system running on a multi-core processor with $128 \mathrm{~GB}$ RAM and a graphics card with $12 \mathrm{MB}$ video RAM. All MRI and $\mu C T$ data sets were processed and transformed into 8-bit TIFF image stacks prior to zero-filling and rotation using the software Fiji/ImageJ 1.53c (Schindelin et al., 2012) and its plugins Polynomial Shading Corrector, TransformJ, and VolumeViewer 2.0. Organ systems in selected image stacks were reconstructed in $3 \mathrm{D}$ using the software Amira 6.7 (FEI Company, Hillsboro, OR, USA) and its Segmentation Editor as well as the SurfaceGen module with "unconstrained smoothing" activated (Ziegler et al., 2018).

\section{Results and discussion}

\section{Comprehensive review of previously published data}

As a prerequisite for attempting to identify the specimens originally presented by Boletzky $(1978-1979,1980$, $1982,1985)$ as well as those introduced here (Specimens $\mathrm{A}-\mathrm{F}$ and $\mathrm{G}-\mathrm{R}$, respectively), previously published data on cirrate egg dimensions, structure, and color were assembled and taxonomically arranged (Table 2). These data on cirrate eggs were differentiated by their location within the female reproductive tract, i.e., inside the ovary (ovum without or with chorion), the proximal oviduct (ovum with chorion), or the distal oviduct (ovum with chorion and egg capsule), and additionally following spawning (ovum with chorion and egg capsule). Furthermore, information on geographic and bathymetric distribution were added. Particular care was taken to identify those taxa, where a considerable gap between chorion and egg capsule would be present following spawning, a feature potentially specific of certain cirrate taxa and first observed by Boletzky (1982). However, more recent observations show that egg capsule size may increase when the freshly secreted egg capsule material comes into contact with seawater and subsequently solidifies (Vecchione et al., 1998).

No spawned egg capsules have yet been documented for any species from the bathy-to-abyssopelagic taxa Cirroteuthis, Cirrothauma, and Stauroteuthis (Cirroteuthidae). However, ova with chorion and surrounding egg capsule are reported from the distal oviduct of several female specimens and here the egg capsules are medium in size, measuring from about $11 \times 6$ to $14 \times 9 \mathrm{~mm}$ (Table 2). Where known, these egg capsules show a rather smooth external aspect and a brown color. Taking chorion dimensions from ovary and proximal oviduct into account, the gap between chorion and egg capsule must be very small.

In the mesopelagic to hadal Grimpoteuthitidae (Cryptoteuthis, Grimpoteuthis, Luteuthis), data on eggs are available for two of the three genera. While egg characteristics are unknown for Cryptoteuthis, species in the other two genera produce large egg capsules, measuring from about $18 \times 11$ to $26 \times 17 \mathrm{~mm}$ (Table 2). However, egg capsules in Luteuthis are reported to possess a smooth external structure with light color, while those of Grimpoteuthis are showing irregular structuring with a muddy brown to greenish color. Recently, an egg capsule measuring $19 \times 14 \mathrm{~mm}$ attached to a large colony of the deep-sea octocoral (Cnidaria: Octocorallia) species Chrysogorgia artospira (Alcyonacea: Chrysogorgiidae) was unequivocally shown to be a representative of the genus Grimpoteuthis (Shea et al., 2018). As the particular behavior of using octocorals as substrate for egg capsule deposition has not been documented from other cirrate taxa yet, it must at present be assumed to be a specific feature of selected or potentially all species pertaining to that particular genus. Where available, the data suggest the presence of a large gap between chorion and egg capsule, at least in freshly spawned specimens (Table 2).

Species in the meso-to-bathypelagic Cirroctopodidae (Cirroctopus) produce large egg capsules ranging in size from about $16 \times 10$ to $22 \times 14 \mathrm{~mm}$. The external structure of the egg capsule has been reported as smooth to irregular with beige or tan color (Table 2). However, ova with chorion and surrounding egg capsule found free in the 


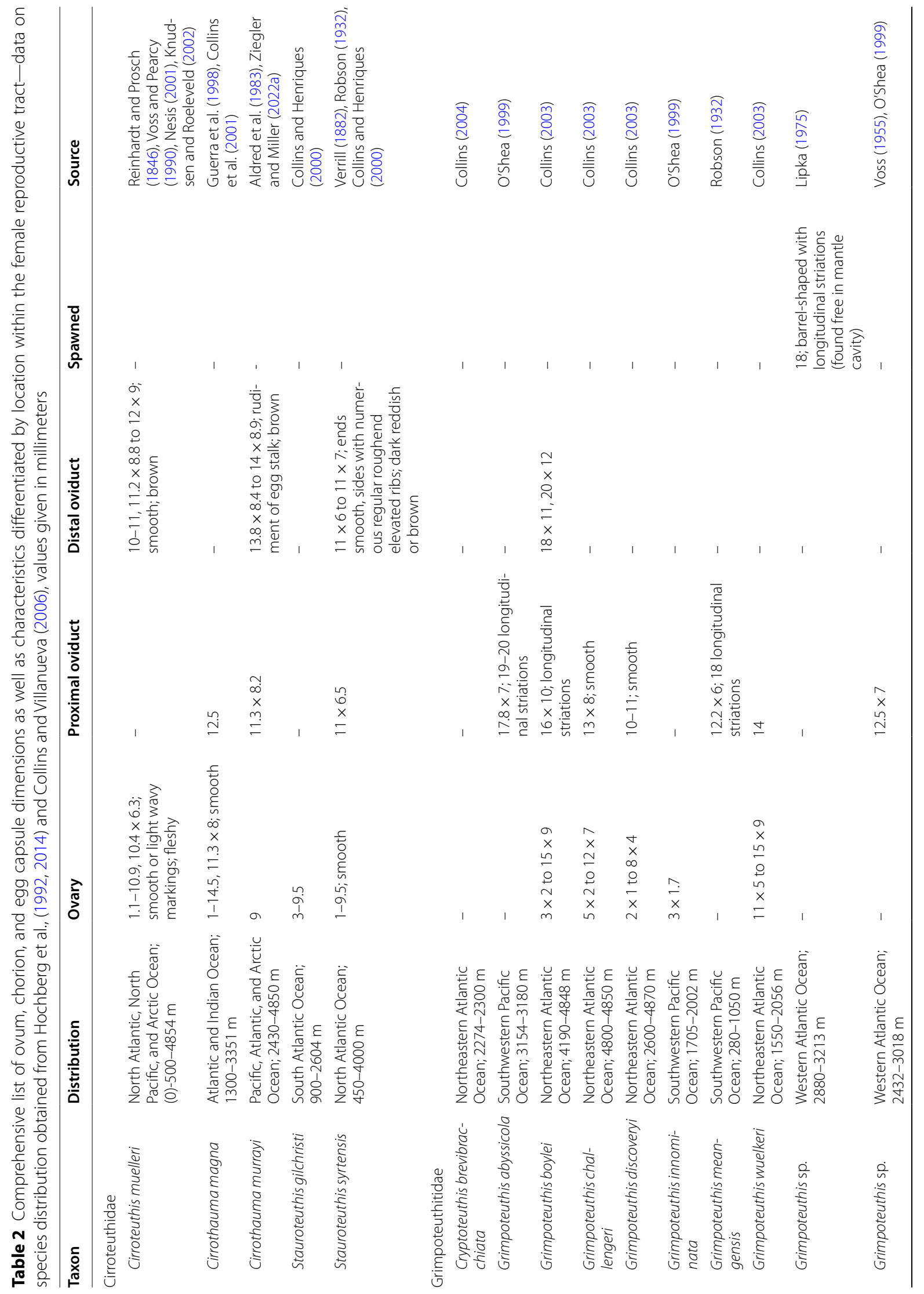




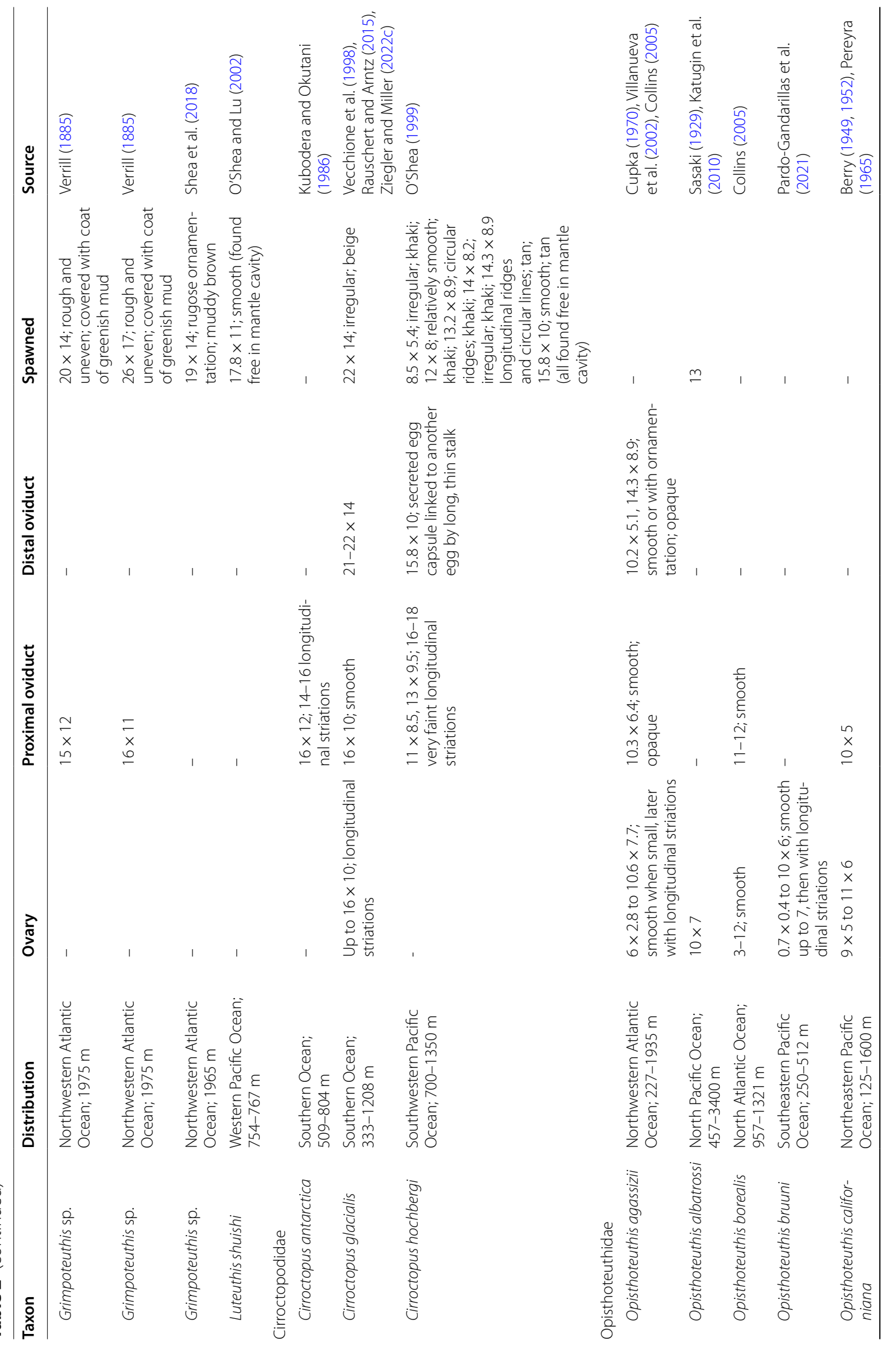




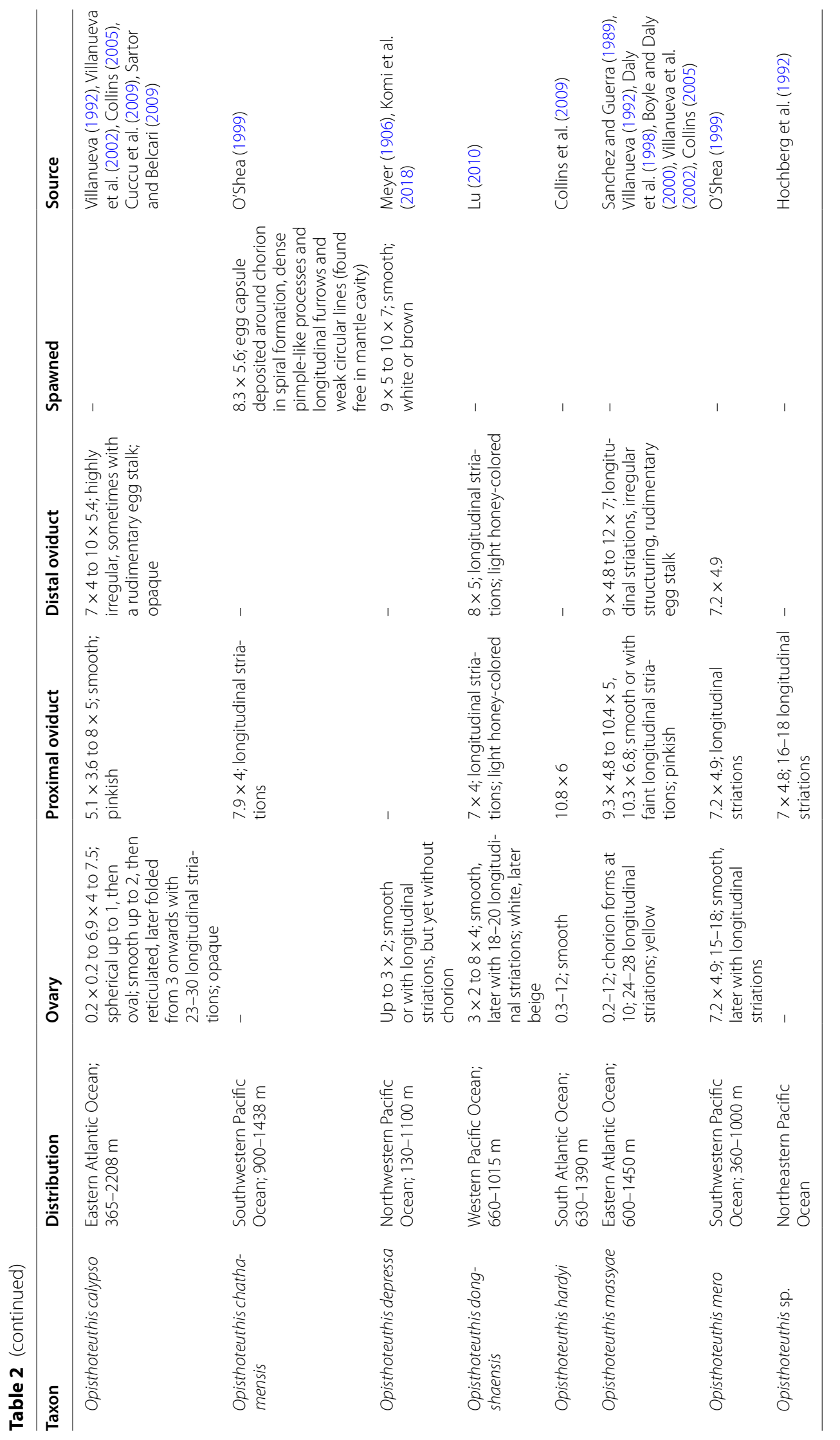




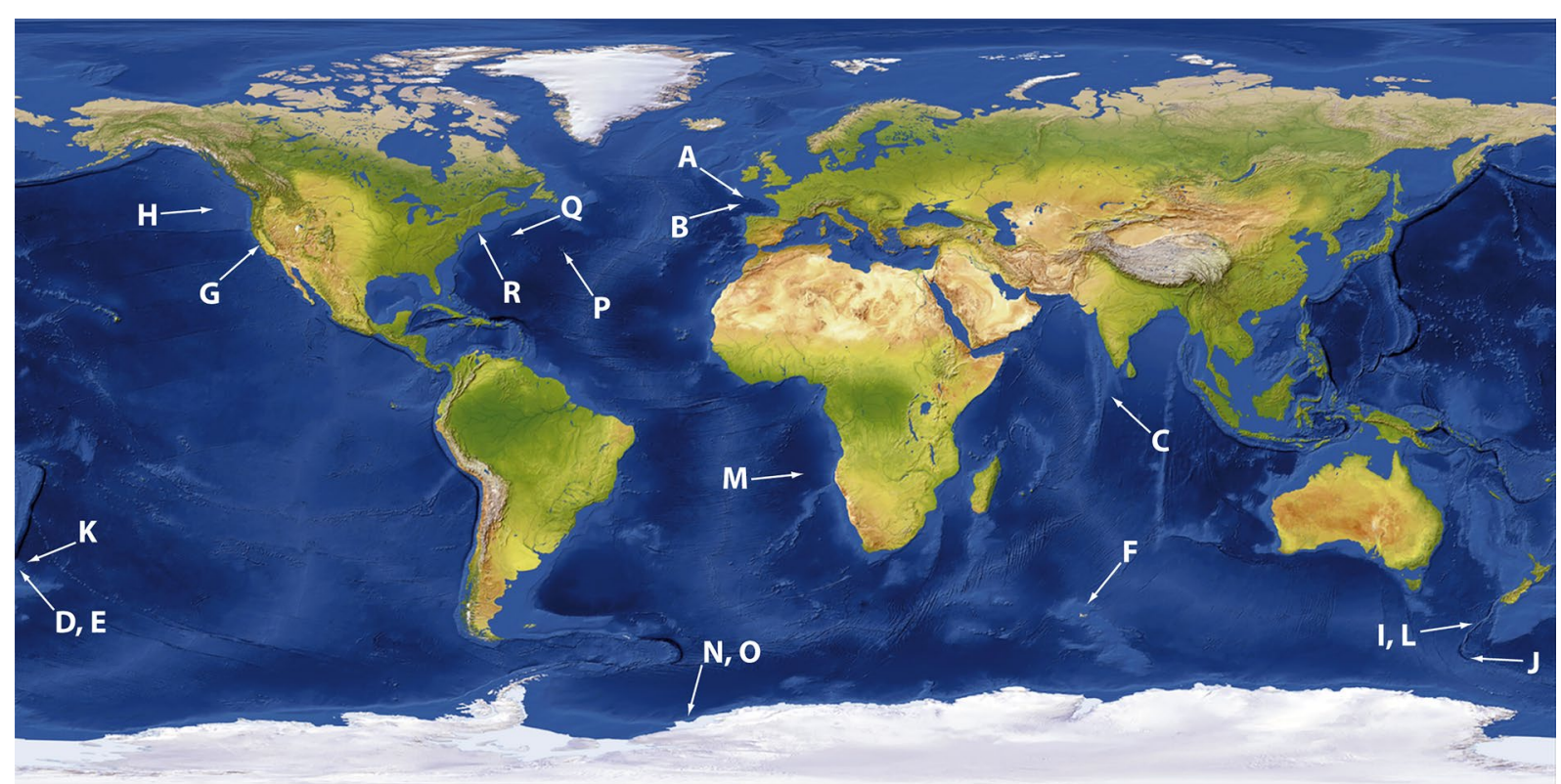

Fig. 1 World map depicting the locality of specimens incorporated into this study

mantle cavity of a single female specimen of Cirroctopus hochbergi showed significant variation in size (ca. $9 \times 5$ to $16 \times 10 \mathrm{~mm}$ ), external structuring (smooth, irregular, circular or longitudinal ridges, circular lines), as well as color (tan or khaki). While such a degree of egg capsule variation has not yet been documented from any other cirrate species, this finding could indicate that caution has to be taken when using egg capsule characteristics as taxonomic proxies (O'Shea, 1999). Nonetheless, the available data suggest that there is a small or even significant gap between chorion and egg capsule (Table 2).

In the epi-to-bathypelagic Opisthoteuthidae (Opisthoteuthis) data on egg characteristics are available for several species (Table 2). In general, the egg capsules are small to medium in size, measuring from about $7 \times 4$ to $14 \times 9 \mathrm{~mm}$. Externally, the egg capsule is smooth with little or significant irregular ornamentation and white to brown color. Based on chorion dimensions from ovary and proximal oviduct, the gap between the chorion and egg capsule must be very small.

These findings for all four cirrate families result in a matrix using egg capsule dimensions, presence of a gap between chorion and egg capsule, as well as geographic and bathymetric distribution as key features for the identification of cirrate eggs collected without an associated adult specimen. In the following section, these key features as well as other data will be used to identify a broad range of early cirrate life stage specimens down to at least genus level.

\section{Specimen A \\ Description}

Collected in 1974 on the Meriadzec Terrace, northeastern Atlantic Ocean at $2860 \mathrm{~m}$ depth during cruise BIOGAS 5 (Table 1, Fig. 1). The size of the partially ruptured egg capsule is estimated to be around $13 \times 10 \mathrm{~mm}$, its external structure shows high and sharp ridges arranged in a hexagonal pattern, the color is brown (Fig. 2a). The chorion measures about $12.5 \times 9.5 \mathrm{~mm}$, leaving practically no gap towards the surrounding egg capsule. At about $10 \mathrm{~mm}$ length, the large external yolk sac almost entirely fills the internal volume of the chorion. A small embryo can be seen lying on top of the external yolk sac. Its dimensions are: $5 \mathrm{~mm}$ total length (TL), $4 \mathrm{~mm}$ mantle length (ML), $2.5 \mathrm{~mm}$ mantle width (MW), $3 \mathrm{~mm}$ fin length (FL), $2 \mathrm{~mm}$ fin width (FW), and $1 \mathrm{~mm}$ arm length (AL). The primary web has not yet formed, the arm tips are rounded, no cirri are visible, but sucker rudiments can be discerned.

\section{Remarks}

Based on egg capsule dimensions, absence of a gap, as well as locality and bathymetry, this specimen is identified as a representative of the Cirroteuthidae, most likely Cirrothauma murrayi.

\section{Specimen B \\ Description}

Egg capsule obtained in 1974 on the Biscay Abyssal Plain, northeastern Atlantic Ocean from 4715 m depth during 


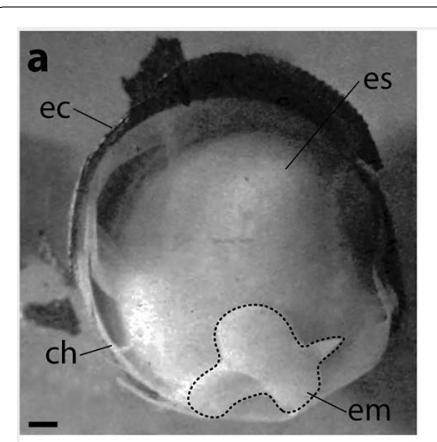

d
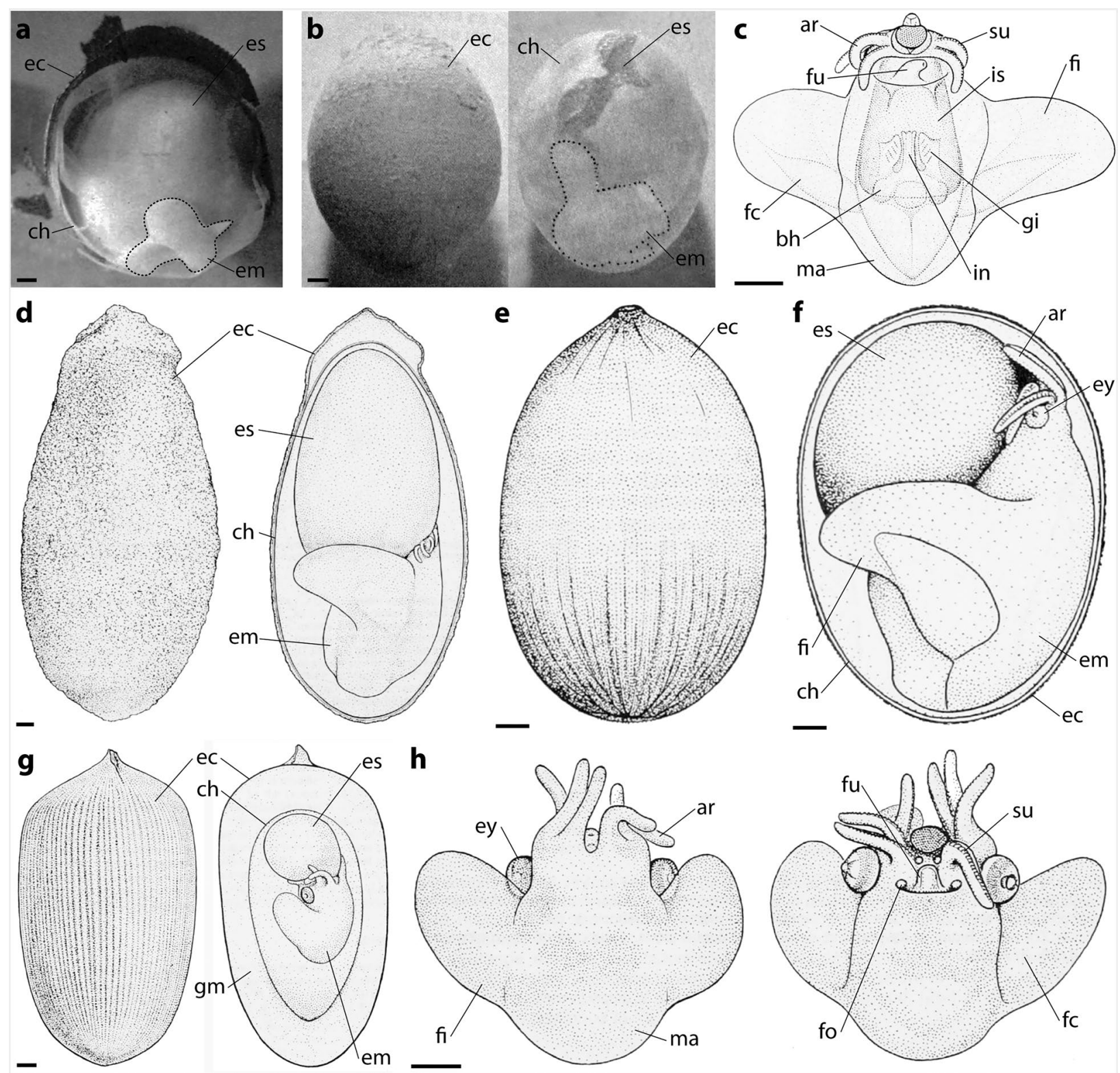

Fig. 2 Cirrate egg capsules and embryos described and pictured by the late Dr. Sigurd von Boletzky. a Specimen A: longitudinally opened egg capsule with chorion, large external yolk sac, and embryo (dotted outline). b Specimen B: intact egg capsule (left) and extracted chorion (right) with large external yolk sac and embryo (dotted outline). c Specimen B: extracted embryo detached from external yolk sac, ventral view. d Specimen C: intact egg capsule with irregular structuring (left) and longitudinally opened egg capsule exposing chorion, large external yolk sac, and embryo (right). e Specimen D: intact egg capsule with longitudinal striations. f Specimen E: Iongitudinally opened egg capsule with chorion, large external yolk sac, and embryo. $\mathbf{g}$ Specimen F: intact egg capsule with longitudinal striations (left) and longitudinally opened egg capsule with chorion, small external yolk sac, and embryo_-note the conspicuous gap between chorion and egg capsule (right). h Specimen F: extracted embryo detached from external yolk sac, dorsal (left) and ventral view (right). $\mathbf{a}-\mathbf{h}$ Modified after Boletzky (1982). ar = arm, bh= branchial heart, ch =chorion, ec = egg capsule, em = embryo, es = external yolk sac, ey= eye, fc = fin cartilage, fi= fin, fo = funnel organ, fu=funnel, gi = gill, gm $=$ gelatinous matter, in = intestine, is = internal yolk sac, ma = mantle, su=sucker. Scale bars $=1 \mathrm{~mm}$

cruise BIOGAS 6 (Table 1, Fig. 1). The egg-shaped egg capsule measures $12 \times 9 \mathrm{~mm}$ and has a coarse surface with inconspicuous longitudinal striations and beige color (Fig. 2b). As in the previous specimen, the chorion with about $11.5 \times 8.5 \mathrm{~mm}$ almost entirely fills the inner volume of the egg capsule, thus leaving no gap between the two structures. An embryo can be seen lying on top of the large external yolk sac that at about $11 \mathrm{~mm}$ length 
fills out almost the entire inner volume of the chorion (Fig. 2b). The extracted embryo is measured at $6.5 \mathrm{~mm}$ TL, $5 \mathrm{~mm} \mathrm{ML}, 3 \mathrm{~mm} \mathrm{MW,} 3 \mathrm{~mm}$ FL, $2 \mathrm{~mm}$ FW, $1.5 \mathrm{~mm}$ $\mathrm{AL}$, and $0.8 \mathrm{~mm}$ funnel length (FuL). No primary web and cirri are present yet, but sucker rudiments can be seen lining the arms with their rounded arm tips (Fig. 2c). The funnel is prominent, but no funnel organ is visible. The translucent mantle and fin tissues permit discerning several internal structures, such as a simple (i.e., unilobular) internal yolk sac, elongated gills, branchial hearts, the distal part of the intestine, and elongated fin cartilages with pointed ends (Fig. 2c).

\section{Remarks}

The key features of the egg capsule (dimensions, absence of a gap, locality, and depth) and embryo (gill shape) lead us to assigning this specimen to the Cirroteuthidae, presumably Cirrothauma murrayi.

\section{Specimen C \\ Description}

This specimen was collected in the Laccadive Sea, Indian Ocean during cruise GALATHEA II (1950-1952) at $4425 \mathrm{~m}$ depth (Table 1, Fig. 1). The elongated, almost elliptical egg capsule measures $24 \times 11 \mathrm{~mm}$ and has an irregularly structured and coarse surface with beige color as well as a slightly deformed apical area (Fig. 2d). The chorion is about $23 \times 10.5 \mathrm{~mm}$ in size and contains a large external yolk sac measuring $14 \times 9 \mathrm{~mm}$ as well as an attached embryo. The embryo measures $11 \mathrm{~mm}$ TL, $10 \mathrm{~mm} \mathrm{ML}, 6 \mathrm{~mm} \mathrm{FL}, 4 \mathrm{~mm}$ FW, and $1 \mathrm{~mm} \mathrm{AL}$. The eyes are small and covered by the short, reflected arms with their rounded arm tips (Fig. 2d). A primary web and cirri have not formed yet, while sucker rudiments are already present. The semi-transparent mantle tissues reveal the presence of a U-shaped shell as well as elongated fin cartilages with rounded ends.

\section{Remarks}

Based on egg capsule dimensions, presence of a U-shaped shell as well as locality and bathymetry, this specimen is identified as a representative of the genus Grimpoteuthis. While the presence of a large gap between chorion and egg capsule was shown to be a key feature of this taxon (Table 2), this particular character might only be present for a given time during ontogeny (see specimens $\mathrm{H}$ and $\mathrm{M}$ below).

\section{Specimen D}

\section{Description}

Egg capsule collected 1950-1952 on the Hikurangi Plateau, southwestern Pacific Ocean at $4520 \mathrm{~m}$ depth during cruise GALATHEA II (Table 1, Fig. 1). At $12.5 \times 8 \mathrm{~mm}$, this egg capsule has an egg-shaped form and shows a fairly smooth external structuring with faint longitudinal striations predominantly at both ends as well as a brown color (Fig. 2e). The embryo found inside has $5 \mathrm{~mm} \mathrm{TL}$, while the large external yolk sac is $7.5 \mathrm{~mm}$ in length (not figured). The embryo's fins are well developed, but no primary web has formed yet. The arms are short and have rounded tips, but they do not show any cirri.

\section{Remarks}

Taking bathymetry, locality, as well as egg capsule characteristics and dimensions into consideration, this specimen is identified as a member of the Cirroteuthidae, most likely Cirrothauma.

\section{Specimen E \\ Description}

Collected 1950-1952 during cruise GALATHEA II on the Hikurangi Plateau, southwestern Pacific Ocean at 4625 m depth (Table 1, Fig. 1). Oval egg capsule measuring $12.5 \times 8 \mathrm{~mm}$ with a rough and sandy surface and beige color. The chorion is $12 \times 7.5 \mathrm{~mm}$ large and there is practically no gap between chorion and egg capsule (Fig. 2f). The external yolk sac measures $7 \times 5 \mathrm{~mm}$ with almost the remainder of the volume inside the chorion being occupied by the embryo. The embryo has the following dimensions: $11 \mathrm{~mm}$ TL, $9 \mathrm{~mm} \mathrm{ML}, 5 \mathrm{~mm}$ FL, $3 \mathrm{~mm}$ FW, $2 \mathrm{~mm} \mathrm{AL}$, and $0.8 \mathrm{~mm}$ eye diameter (ED). The primary web has not formed yet and cirri are absent, too. The arms have rounded tips and show sucker rudiments (Fig. 2f).

\section{Remarks}

Based on egg capsule dimensions, absence of a gap, as well as locality and collection depth, this specimen is identified as a representative of the Cirroteuthidae, most likely Cirrothauma.

\section{Specimen $\mathbf{F}$ \\ Description}

Egg capsule obtained from 1218 m depth on the Kerguelen Plateau, southern Indian Ocean in 1975 during cruise MD04/BENTHOS (Table 1, Fig. 1). The egg capsule measures $16 \times 9 \mathrm{~mm}$ and externally has numerous longitudinal striations and a brown color (Fig. 2g). The chorion is much smaller, measuring $11 \times 6 \mathrm{~mm}-$ the gap between chorion and egg capsule is filled with a gelatinous matter (Boletzky, 1982). Inside the chorion, a small external yolk sac of ca. $5 \times 4 \mathrm{~mm}$ size can be seen, attached to the yolk sac is an embryo (Fig. $2 \mathrm{~g}$ ). The embryo measures $5.5 \mathrm{~mm}$ TL, $4 \mathrm{~mm} \mathrm{ML}, 3 \mathrm{~mm} \mathrm{MW}$, $2.5 \mathrm{~mm} \mathrm{FL}, 2 \mathrm{~mm}$ FW, $1.5 \mathrm{~mm} \mathrm{AL}, 0.9 \mathrm{~mm}$ ED, and 
$0.5 \mathrm{~mm}$ FuL. Its primary web has not yet formed, the arm tips are rounded, and there are no cirri yet, but sucker rudiments can be seen (Fig. 2h). Notable are the posterior edges of the fins, which are continuous with the posterior mantle end as well as the fact that the eyes are not yet covered by the corneal skin. In addition, the funnel organ is already visible at this stage.

\section{Remarks}

Using egg capsule dimensions, presence of a large gap, fin and mantle morphology as well as locality and bathymetry as relevant characters, this specimen is identified as a representative of the genus Cirroctopus.

\section{Specimen G}

\section{Description}

This single egg capsule was attached to the wall of an aquarium by a female cirrate (Opisthoteuthis sp.) collected alive from the Monterey Canyon, northeastern Pacific Ocean in 1992 at 200-400 m depth (Table 1, Fig. 1). The elongated egg capsule measures $10 \times 4 \mathrm{~mm}$ and is predominantly smooth with occasional sediment particles embedded into its exterior (Fig. 3a). The egg capsule has a beige color and tightly encloses a chorion measuring $6 \times 3 \mathrm{~mm}$ (Fig. 3b). There is no gap between chorion and egg capsule as well as no sign of an embryo.

\section{Remarks}

Based on egg capsule dimensions and absence of a gap as well as sampling locality and depth, this specimen is identified as pertaining to a representative of the genus Opisthoteuthis, potentially O. californiana. However, unpublished data as well as adult specimens collected by Frederick G. Hochberg indicate the presence of a yet undescribed species of Opisthoteuthis along the California coastline (Daniel Geiger, personal communication).

\section{Specimen $\mathrm{H}$}

\section{Description}

Collected in 1972 during cruise Y7210A on the Tufts Abyssal Plain, northeastern Pacific Ocean at $3900 \mathrm{~m}$ depth (Table 1, Fig. 1), this egg capsule measures $19 \times 12 \mathrm{~mm}$. It has an elongated egg-shaped form, irregular external structuring, and a muddy greyish color (Fig. 3c). At $12 \times 8 \mathrm{~mm}$ the chorion is much smaller than the egg capsule and contains a large external yolk sac that almost entirely occupies its inner volume. No sign of an embryo is found (Fig. 3c).

\section{Remarks}

Given egg capsule dimensions and structuring, the presence of a large gap, and locality as well as bathymetry, this specimen is identified as pertaining to a species within the genus Grimpoteuthis. More specifically, this egg capsule is very likely either from an adult of G. bathynectes or G. tuftsi, as these two species have been found to inhabit the exact area-in fact, during the same haul on cruise Y7210A, an adult male specimen of G. tuftsi (SBMNH 35146) was collected (Voss \& Pearcy, 1990).

\section{Specimen I \\ Description}

Egg capsule collected in 2008 during cruise TAN0803 on the Macquarie Ridge Complex, southwestern Pacific Ocean at 1087-1160 m depth (Table 1, Fig. 1). Measuring $15 \times 8 \mathrm{~mm}$, the rounded egg capsule has numerous longitudinal striations and a light brown color-note the smooth, white-colored chorion that can be seen through an artificial rupture of the egg capsule (Fig. 3d). Using MRI, the internal composition of the egg capsule can be analyzed: the chorion is much smaller than the surrounding egg capsule and measures $11.5 \times 7.5 \mathrm{~mm}$, the gap being filled with some kind of organic (gelatinous?) matter (Fig. 3e). The external yolk sac is smaller than the chorion as well, measuring $10 \times 6 \mathrm{~mm}$, but no sign of an embryo is found. On average, the thickness of the egg capsule is ca. $150 \mu \mathrm{m}$ and that of the chorion ca. $100 \mu \mathrm{m}$.

\section{Remarks}

Based on the presence of a large gap and egg capsule dimensions, form, and structuring as well as sampling locality and depth, this egg capsule is identified as a representative of the genus Cirroctopus.

\section{Specimen J}

\section{Description}

This single egg capsule was collected during cruise TAN0803 on the Macquarie Ridge Complex, southwestern Pacific Ocean at 1400-1615 m depth (Table 1, Fig. 1). In its overall aspect it is very similar to the previous specimen. However, it measures $16 \times 9 \mathrm{~mm}$ and on one side is covered by a white cristalline matter (Fig. 3f). The opposite side shows conspicuous imprints that are here judged to be the area of attachment of the egg capsule to a hard substrate (Fig. 3f). MRI data reveal the presence of organic (gelatinous?) matter in-between the chorion and egg capsule. The chorion measures $12 \times 7.5 \mathrm{~mm}$. The large external yolk sac in turn measures $9.5 \times 5.5 \mathrm{~mm}$, but there is no sign of an embryo (Fig. $3 \mathrm{~g}, \mathrm{~h}$ ). Average thickness of chorion and egg capsule are the same as for the previous specimen.

\section{Remarks}

In consequence, this egg capsule is identified as pertaining to a species of Cirroctopus as well. 


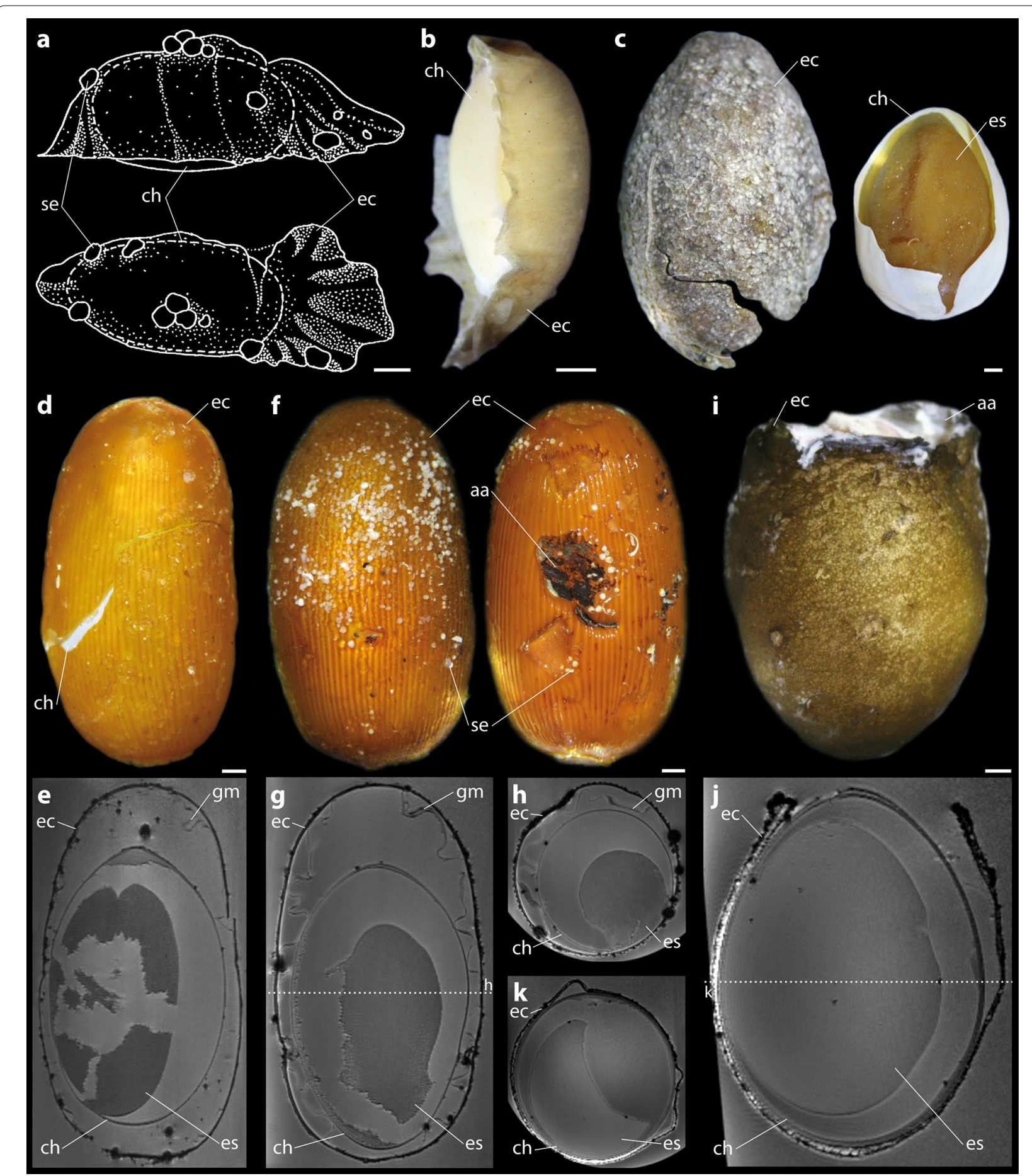

Fig. 3 Cirrate egg capsules without macroscopically visible embryos. a Specimen G: egg capsule with chorion and sediment particles, lateral (above) and top view (below). b Specimen G: egg capsule with chorion, lateral view. c Specimen H: egg capsule with irregular structuring (left) and extracted chorion with large external yolk sac (right). $\mathbf{d}$ Specimen l: egg capsule with longitudinal striations and rupture exposing chorion. e Specimen I: virtual longitudinal section through 3D MRI data set showing chorion and external yolk sac-note the conspicuous gap between chorion and egg capsule.f Specimen J: egg capsule with longitudinal striations and white cristalline matter (left) as well as potential attachment areas to a hard substrate (right). $\mathbf{g}$ Specimen J: virtual longitudinal section showing chorion and external yolk sac. i Specimen K: egg capsule with potential apical attachment area to a hard substrate. j Specimen K: virtual longitudinal section showing chorion and external yolk sac-note the absence of a gap between chorion and egg capsule. Image a courtesy Frederick G. Hochberg. aa $=$ attachment area, $c h=c h o r i o n, ~ e c=e g g$ capsule, es = external yolk sac, gm = gelatinous matter, se $=$ sediment. Scale bars $=1 \mathrm{~mm},(\mathbf{e}-\mathbf{h}, \mathbf{k}, \mathbf{j})$ not to scale 


\section{Specimen K}

\section{Description}

Collected in 1998 during cruise NZOI SOP on the Hikurangi Plateau, southwestern Pacific Ocean at 1003$1108 \mathrm{~m}$ depth (Table 1, Fig. 1), this egg capsule measures $12 \times 9 \mathrm{~mm}$. It has a relatively smooth exterior with some irregular structuring and an olivine color (Fig. 3i). At one end, the egg capsule is very likely to have been attached to a hard substrate. Using MRI, the chorion can be readily discerned: it measures $11.6 \times 8.5 \mathrm{~mm}$, thus leaving practically no gap towards the egg capsule (Fig. $3 j$ ). The external yolk sac is relatively large and at $9.5 \times 7 \mathrm{~mm}$ fills the inner volume of the chorion to some extent (Fig. 3k). In contrast to specimens I and J, the average thickness of the chorion is about $150 \mu \mathrm{m}$, while that of the egg capsule is $300 \mu \mathrm{m}$.

\section{Remarks}

According to the label found with this museum specimen, the egg capsule was assigned to Cirroctopus hochbergi. However, based on egg capsule dimensions and structuring, absence of a gap, as well as sampling locality, this specimen is here identified as pertaining to a member of the Cirroteuthidae, most likely Cirroteuthis.

\section{Specimen L \\ Description}

Severely ruptured egg capsule collected in 2008 during cruise TAN0803 on the Macquarie Ridge Complex, southwestern Pacific Ocean at 1087-1160 m depth (Table 1, Fig. 1). The original dimensions of the egg capsule are difficult to ascertain, but it closely resembles specimens I and J with regard to external structuring and color (Fig. 4a). The chorion is significantly smaller than the egg capsule and measures $11 \times 4 \mathrm{~mm}$. Using contrastenhanced $\mu \mathrm{CT}$ it can be shown that the chorion contains an embryo attached to the largely amorphous mass of the external yolk sac (Fig. 4b). At about $1 \mathrm{~mm} \mathrm{ML}$, this embryo represents the smallest cirrate embryo on record. It has a large rounded mantle with proportionally very large eyes (Fig. 4c). The primary web has not formed yet and cirri are not discernible as well, although a few sucker rudiments are present. A reconstruction of the shell shows this organ to be open U-shaped (Fig. 4d).

\section{Remarks}

The embryonic features in combination with the egg capsule characteristics underline the previous assessment of this type of egg capsule pertaining to a species within the genus Cirroctopus.

\section{Specimen M}

\section{Description}

Single egg capsule collected in 2000 during cruise DIVA-1 from the Angola Basin, southeastern Atlantic Ocean at $5400 \mathrm{~m}$ depth (Table 1, Fig. 1). The egg capsule measures about $20 \times 15 \mathrm{~mm}$ and shows highly irregular structuring and a muddy greenish color (Fig. 4e). Particularly noteworthy is the fact, that the chorion seemingly has swollen, thus rupturing the surrounding, much thicker and tougher egg capsule. While this could represent an artifact caused by the changes of the physico-chemical conditions occurring during sampling from a deep-sea habitat, swollen chorions rupturing their enclosing egg capsules were recently shown to occur in situ as well (Vecchione, 2019). Following extraction and artificial opening of the chorion, a large external yolk sac and an embryo are exposed (Fig. 4f). The embryo provides the following measurements: $13 \mathrm{~mm} \mathrm{TL}$, $10 \mathrm{~mm} \mathrm{ML}, 6 \mathrm{~mm} \mathrm{MW,} 9 \mathrm{~mm}$ FL, $3.5 \mathrm{~mm}$ FW, $3 \mathrm{~mm}$ AL, and $1.5 \mathrm{~mm}$ FuL. Through its semi-transparent mantle and fin tissues, large and elongated fin cartilages with pointed ends (Fig. 4g) as well as circular-shaped gills and the distal part of the intestine can be seen (Fig. 4h). The arm crown seems to be only basally connected by a small primary web, while the arms with their rounded arm tips show no cirri, but sucker rudiments are present (Fig. 4h). A small funnel can be seen, but no funnel organs are yet discernible.

\section{Remarks}

Egg capsule dimensions and structuring as well as color in addition to bathymetry suggest that this specimen constitutes a representative of the genus Grimpoteuthis. In fact, during the same cruise an adult specimen identified as $G$. wuelkeri was obtained in the vicinity (Piatkowski \& Diekmann, 2005).

\section{Specimens $\mathrm{N}$ and $\mathrm{O}$ \\ Description}

Both specimens were collected in 1996 during cruise ANTARKTIS XIII/3 off Brunt Ice Shelf, Southern Ocean at 620-640 $\mathrm{m}$ depth (Table 1, Fig. 1). This specimen lot comprises two chorions and two embryos, but lacks egg capsules as well as external yolk sacs. The smaller embryo (Specimen N) measures $9 \mathrm{~mm} \mathrm{TL}$, $5 \mathrm{~mm} \mathrm{ML}, 5 \mathrm{~mm} \mathrm{MW,} 3 \mathrm{~mm}$ FL, $2 \mathrm{~mm}$ FW, $4 \mathrm{~mm} \mathrm{AL}$, $1 \mathrm{~mm} \mathrm{ED}$, and $1.5 \mathrm{~mm}$ FuL. Its subterminal fins are relatively short, almost square, and their posterior edges merge with the posterior end of the mantle (Fig. 5a). The primary web is well developed and the arms possess suckers as well as rudimentary cirri. Areolar spots are present on the dorsal side of the mantle (Fig. 5a, c). The chorion is egg-shaped and relatively inconspicuous 


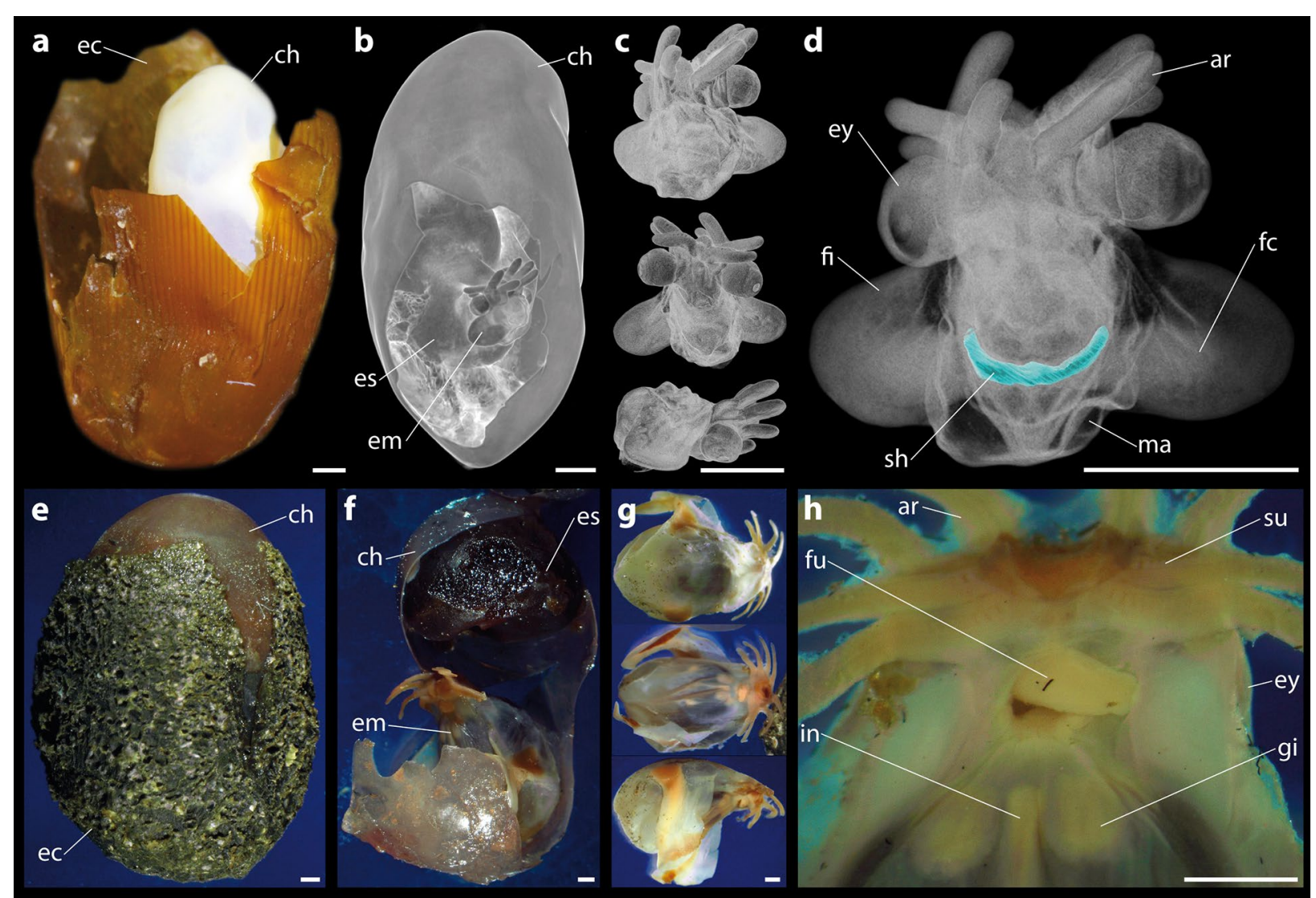

Fig. 4 Cirrate egg capsules with embryos. a Specimen L: unnaturally ruptured egg capsule with longitudinal striations, chorion partially visiblenote the large gap between chorion and egg capsule. $\mathbf{b}$ Specimen $\mathrm{L}$ : volume rendering of a 3D $\mu \mathrm{CT}$ data set of the artificially opened chorion showing embryo with $1 \mathrm{~mm} \mathrm{ML}$ still attached to the large external yolk sac. c Specimen L: volume renderings of the extracted embryo in dorsal (top), ventral (center), and right lateral view (bottom). d Specimen L: semi-transparent volume rendering of the embryo showing a surface-rendered model of the open U-shaped shell, dorsal view. e Specimen M: egg capsule presumably naturally ruptured due to swelling of the chorion.f Specimen M: extracted and artificially opened chorion showing embryo with $10 \mathrm{~mm} \mathrm{ML} \mathrm{detached} \mathrm{from} \mathrm{large} \mathrm{external} \mathrm{yolk} \mathrm{sac.} \mathrm{g} \mathrm{Specimen} \mathrm{M:}$ extracted embryo in dorsal (top), ventral (center), and right lateral view (bottom). $\mathbf{h}$ Specimen M: close-up ventral view of the embryo's arm crown and funnel aperture - note the absence of cirri. Images (e-h) courtesy Francisco J. Cristobo. ar = arm, ch=chorion, ec=egg capsule, em =embryo, es = external yolk sac, ey= eye, $\mathrm{fc}=$ fin cartilage, $\mathrm{fi}=\mathrm{fin}, \mathrm{fu}=\mathrm{funnel}, \mathrm{gi}=$ gill, in = intestine, $\mathrm{ma}=$ mantle, $\mathrm{sh}=$ shell, su=sucker. Scale bars $=1 \mathrm{~mm}$

(Fig. 5b). A large part of the internal volume of this embryo is filled with the simple (i.e., unilobular) internal yolk sac (Fig. 5a, d). The elongated fin cartilages with pointed ends attach to an open U-shaped shell that shows a central depression, giving it a shallow W-shaped appearance (Fig. 5d). It is unclear how many optic nerve bundles exactly penetrate the white body, but there appear to be at least three. The larger embryo (Specimen O) measures $16 \mathrm{~mm} \mathrm{TL}, 10 \mathrm{~mm} \mathrm{ML}$, $9 \mathrm{~mm} \mathrm{MW}, 7 \mathrm{~mm} \mathrm{FL}, 4 \mathrm{~mm}$ FW, $6 \mathrm{~mm} \mathrm{AL}, 2.5 \mathrm{~mm}$ ED, and $2.5 \mathrm{~mm}$ FuL. The fins are long and situated laterally (Fig. 5e). The primary web is deep and the arms possess well-developed suckers and cirri (Fig. 5h), while a line of areolar spots can be barely made out on the dorsal side of the mantle (Fig. 5e). As in the smaller embryo, the chorion is relatively inconspicuous as well (Fig. 5f). A large part of the internal volume of this embryo is filled with the simple (i.e., unilobular) internal yolk sac (Fig. 5e). Due to the relatively bad state of preservation of this latter specimen, several aspects of its internal anatomy cannot be analyzed.

\section{Remarks}

Based on sampling location and depth as well as selected embryonic features (presence of areolar spots, fin and shell shape, number of optic nerve bundles), these two embryos are identified as representatives of the genus Cirroctopus. 


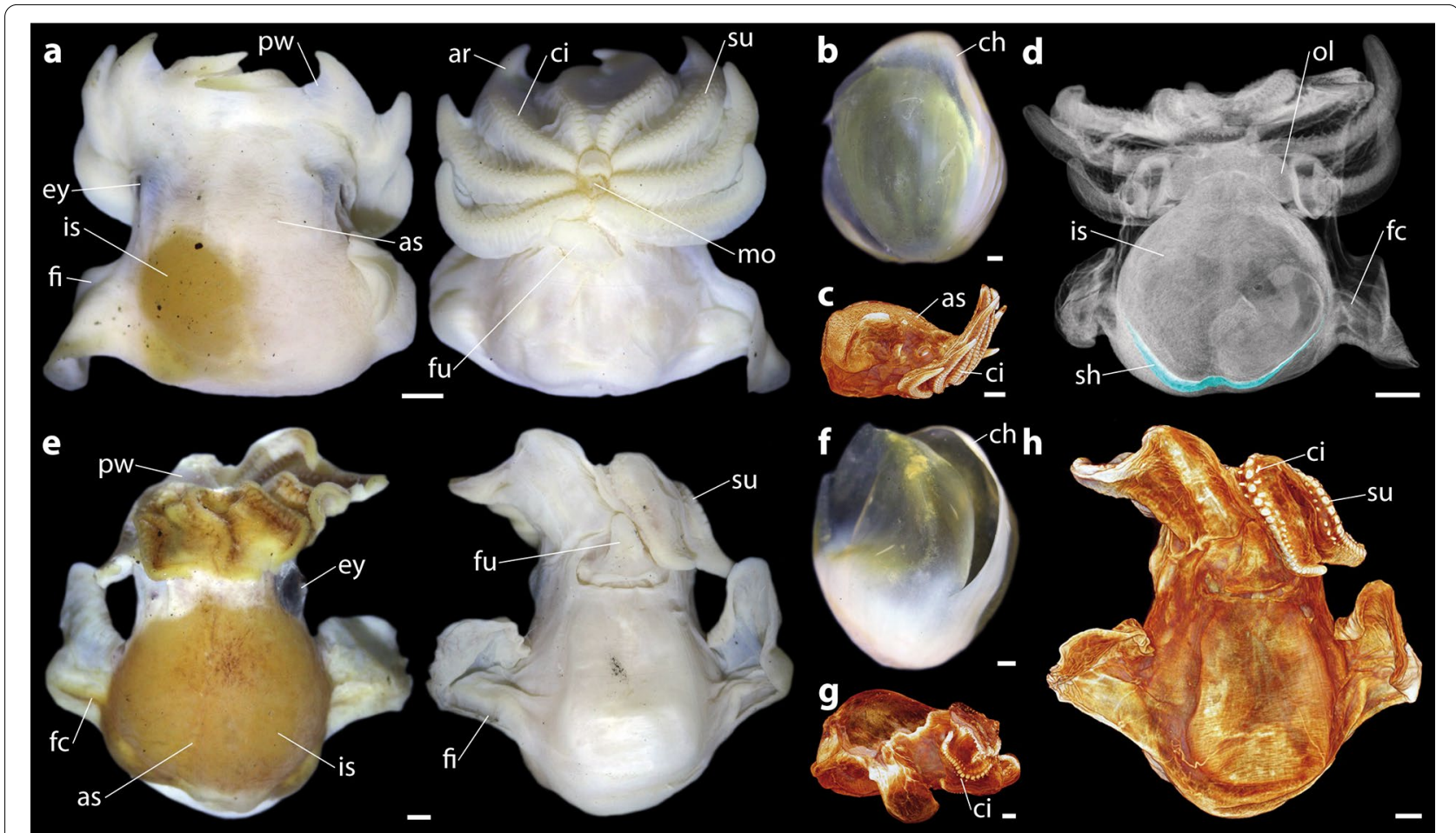

Fig. 5 Cirrate embryos with associated chorions. a Specimen N: extracted embryo with $5 \mathrm{~mm} \mathrm{ML}$, dorsal (left) and ventral view (right). The yellow-colored internal yolk sac can partially be seen through the artificially semi-transparent mantle tissue. b Specimen N: longitudinally ruptured chorion. c Specimen N: volume rendering of a contrast-enhanced 3D $\mu \mathrm{CT}$ data set of the embryo, right lateral view. $\mathbf{d}$ Specimen N: semi-transparent volume rendering of a contrast-enhanced $3 \mathrm{D} \mu \mathrm{CT}$ data set of the embryo showing the wide U-shaped shell with central depression as well as further internal structures. e Specimen O: extracted embryo with $10 \mathrm{~mm} \mathrm{ML}$, dorsal (left) and ventral view (right). The yellow-colored internal yolk sac can almost fully be seen through the artificially semi-transparent mantle tissue. f Specimen O: longitudinally ruptured chorion. $\mathbf{g}$ Specimen O: volume rendering of a contrast-enhanced 3D $\mu \mathrm{CT}$ data set of the embryo, right lateral view. $\mathbf{h}$ Specimen O: volume rendering of a contrast-enhanced 3D $\mu C T$ data set of the embryo showing suckers and cirri, ventral view. ar $=a r m$, as = aerolar spot, ch $=c h o r i o n, c i=c i r r u s$, ey $=$ eye, $\mathrm{fc}=$ fin cartilage, $\mathrm{fi}=\mathrm{fin}, \mathrm{fu}=$ funnel, is $=$ internal yolk sac, $\mathrm{mo}=$ mouth, ol =optic lobe, $\mathrm{pw}=$ primary web, sh $=$ shell, su $=$ sucker. Scale bars $=1 \mathrm{~mm}$

\section{Specimen $\mathbf{P}$ \\ Description}

Egg capsule collected in 2005 on the Corner Rise Seamounts at $2068 \mathrm{~m}$ depth during cruise Deep Atlantic Stepping Stones (Table 1, Fig. 1). This egg capsule measuring $19 \times 14 \mathrm{~mm}$ was found attached to a large colony of the octocoral species Chrysogorgia tricaulis and has an irregular exterior structuring with beige color-note how part of the egg capsule is wrapped around one of the stems of the octocoral colony (Fig. 6a). Upon arrival on deck the egg capsule ruptured, releasing an embryo (or premature hatchling) with a small external yolk sac still within its arm crown (Fig. 6b). The embryo measures $23 \mathrm{~mm} \mathrm{TL}, 12 \mathrm{~mm} \mathrm{ML}, 10 \mathrm{~mm} \mathrm{MW,} 13 \mathrm{~mm}$ FL, $7 \mathrm{~mm}$ FW, $11 \mathrm{~mm} \mathrm{AL}, 2 \mathrm{~mm}$ ED, and $3 \mathrm{~mm}$ FuL. The primary web is relatively shallow, while cirri and suckers are well-developed (Fig. 6b). MRI data reveal the presence of a simple (i.e., unilobular) internal yolk sac that at its posterior end is partially engulfed by an open U-shaped shell (Fig. 6c). An MRI-based 3D reconstruction of selected internal structures illustrates the large size of the internal yolk sac in relation to other organ systems (Fig. 6d, e). The shell bears elongate fin cartilages with pointed ends (Fig. 6f). The white bodies are each penetrated by a single optic nerve bundle.

\section{Remarks}

The combined data on egg capsule and embryo dimensions as well as characters permit an identification of this specimen as a member of the genus Grimpoteuthis.

\section{Specimen Q \\ Description}

Another single egg capsule was collected in 2005 during cruise Deep Atlantic Stepping Stones on Kelvin Seamount, northwestern Atlantic Ocean at 1965 m depth 


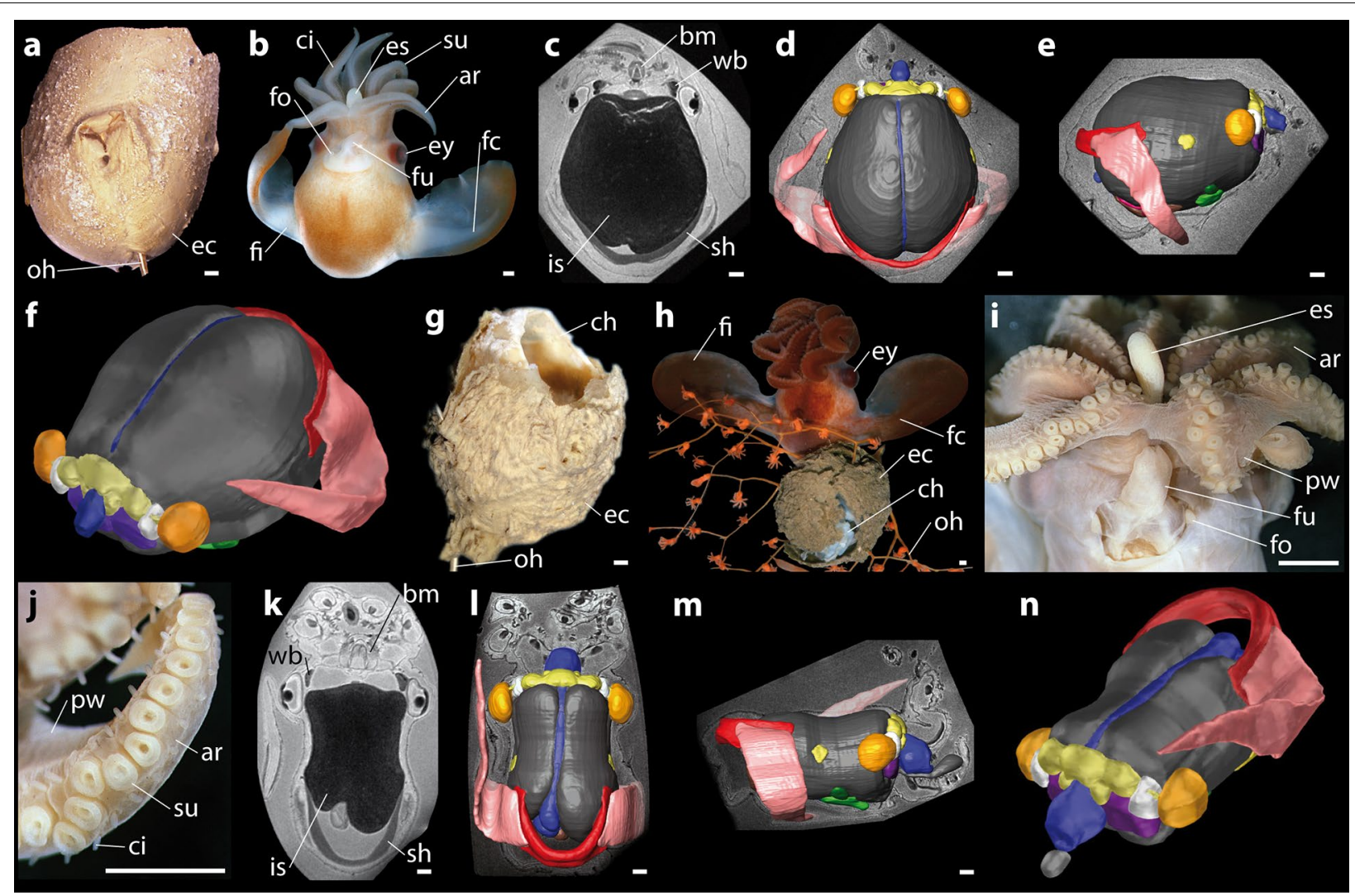

Fig. 6 Cirrate egg capsules with prematurely hatched embryos. a Specimen P: naturally ruptured egg capsule with partially embedded octocoral host. b Specimen P: embryo with $12 \mathrm{~mm}$ ML pictured directly after leaving the egg capsule, ventral view—note small external yolk sac within arm crown. c Specimen P: virtual horizontal section through 3D MRI data set showing large internal yolk sac, shell, white body, buccal mass, as well as other internal organs. (d, e) Specimen P: surface-rendered 3D model of selected internal organs shown with semi-transparent virtual MRI section, dorsal (d) and right lateral view (e). f Specimen P: surface-rendered 3D model of selected internal organs, oblique fronto-dorsal view. g Specimen Q: naturally ruptured egg capsule with partially embedded octocoral host. $\mathbf{h}$ Specimen Q: embryo with $13 \mathrm{~mm} \mathrm{ML}$ shown directly after leaving the egg capsule, dorsal view. i Specimen Q: arm crown of fixed embryo showing small external yolk sac, funnel, funnel organ, and shallow primary web, ventral view. $\mathbf{j}$ Specimen Q: close-up view of arms showing suckers, cirri, and primary web. k Specimen Q: virtual horizontal section through 3D MRI data set showing large internal yolk sac, shell, white body, buccal mass, as well as other internal organs. (I, $\mathbf{m})$ Specimen Q: surface-rendered 3D model of selected internal organs shown with semi-transparent virtual MRI section, dorsal (I) and right lateral view (m). n Specimen Q: surface-rendered 3D model of selected internal organs, oblique fronto-dorsal view. Images $(\mathbf{a}, \mathbf{g}, \mathbf{i}, \mathbf{j})$ courtesy Elizabeth K. Shea, images $(\mathbf{b}, \mathbf{h})$ courtesy Timothy M. Shank. Dark green = branchial glands, dark blue = digestive tract, orange = eyes, pink = fin cartilages, light green = gills,

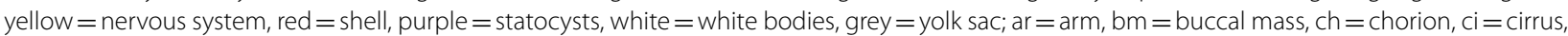
ec = egg capsule, es = external yolk sac, ey= eye, $\mathrm{fc}=$ fin cartilage, $\mathrm{fi}=\mathrm{fin}, \mathrm{fo}=$ funnel organ, fu=funnel, oh=octocoral host, $\mathrm{pw}=$ primary web, $\mathrm{sh}=$ shell, su $=$ sucker, $\mathrm{wb}=$ white body. Scale bars $=1 \mathrm{~mm}$

(Table 1, Fig. 1). Similar to Specimen P, this egg capsule was found attached to an octocoral host, but in this case Chrysogorgia artospira (Shea et al., 2018). The egg capsule measures $19 \times 14 \mathrm{~mm}$ as well, but shows a highly irregular structuring with muddy brownish color (Fig. 6g). This egg capsule also ruptured upon arrival on deck (Fig. 6h), releasing another embryo (or premature hatchling). The embryo measures about $29 \mathrm{~mm} \mathrm{TL}, 13 \mathrm{~mm} \mathrm{ML}$, $11 \mathrm{~mm} \mathrm{MW}, 17 \mathrm{~mm} \mathrm{FL}, 9 \mathrm{~mm}$ FW, $16 \mathrm{~mm} \mathrm{AL}, 2.7 \mathrm{~mm}$ ED, and $3.5 \mathrm{~mm}$ FuL. A small external yolk sac within the arm crown with its relatively shallow primary web is visible as are the funnel organs at the base of the relatively long funnel (Fig. 6i). Suckers can be clearly differentiated into acetabulum and infidibulum, alternating with relatively long cirri (Fig. 6j). MRI data reveal the presence of a simple (i.e., unilobular) internal yolk sac that at its posterior end is partially surrounded by a U-shaped shell (Fig. 6k). An MRI-based 3D reconstruction of selected internal structures illustrates the large size of the internal yolk sac in relation to other organ systems (Fig. 6l, m). The shell attaches to elongate fin cartilages with pointed ends (Fig. 6n). The white bodies are each penetrated by a single optic nerve bundle. 


\section{Remarks}

As for the previous specimen and as previously shown (Shea et al., 2018), this egg capsule and the associated embryo can unequivocally be identified as a representative of the genus Grimpoteuthis.

\section{Specimen $\mathbf{R}$ \\ Description}

Several specimens were collected in 1884 during a cruise by the research vessel Albatross at Hudson Canyon, northwestern Atlantic Ocean at 1975 m depth (Table 1, Fig. 1). In his report on multiple cirrate eggs collected in this part of the Atlantic Ocean at similar depths, Verrill (1885: 410-411) specifically mentions that some of the eggs collected at Hudson Canyon contained well-formed embryos. He provided the following description: "These embryos have a well-developed body, rounded behind, with relatively large, rather broad lateral fins, having the outer ends broadly rounded, situated far forward and as long as the breadth of the body. The eyes are relatively large and prominent, or some-what stalked. The arms are slender, rounded, with a simple close median row of small suckers. The web is but little developed, the arms being free nearly to the base. The siphon-tube is prominent and the gill-opening is simple and small, but relatively larger than in Stauroteuthis syrtensis. It is probable, therefore, that this embryo belongs to one of the species of Cirrhoteuthis described above."

\section{Remarks}

The two new species he assigned to the now invalid genus Cirrhoteuthis are presently considered to be species of Grimpoteuthis (Collins \& Villanueva, 2006). In combination with his description of the relevant egg capsules $(20 \times 14$ and $26 \times 17 \mathrm{~mm}$ with a chorion size of $15 \times 11$ and $16 \times 12 \mathrm{~mm}$, respectively, as well as irregular exterior structuring with a muddy greenish color and egg capsules found attached to octocoral hosts), the information indeed permit identifying these specimens as pertaining to the genus Grimpoteuthis. Unfortunately, the whereabouts of this material are unknown.

\section{Methodological approach}

Sigurd von Boletzky based his descriptions of cirrate egg capsules and embryos on material he had obtained from the collections at the Laboratoire Arago in Banyuls, France as well as the Muséum National d'Histoire Naturelle (MNHN) in Paris, France (Boletzky, 1982). Apart from observing and describing the external characteristics of egg capsules as previous authors had done (Table 2), von Boletzky was the first to also histologically study cirrate embryos (Boletzky, 1982). Given the small dimensions of embryos as well as the kind of anatomical information desired, histology obviously constitutes the method of choice for analysis. However, the scarceness of early cirrate life stage material dictates the application of alternative, ideally non-invasive techniques prior to any form of destructive analysis. Such an approach-based on MRI-was recently shown to be effective in studying the anatomy of a prematurely hatched cirrate embryo (Shea et al., 2018), but was later also used to gather anatomical data suitable for a full species description using an adult cirrate specimen collected in the northwestern Pacific Ocean (Werner et al., 2016; Ziegler, 2021; Ziegler \& Sagorny, 2021). The present study extends this approach by applying MRI to intact cirrate egg capsules as well as contrast-enhanced $\mu \mathrm{CT}$ to cirrate embryos (Ziegler, 2019; Ziegler et al., 2018). However, while the isotropic voxel resolution achieved here both using MRI and $\mu$ CT may be sufficient to differentiate between major egg capsule structures as well as embryonic organ systems (Figs. 3, 4, 5, 6), conventional histology obviously offers the advantage of specific staining (Ziegler \& Menze, 2013; Ziegler et al., 2018) and as such would be better suited for a detailed anatomical description of cirrate embryonic material. Although the exact whereabouts of the histological sections of cirrate embryos made by von Boletzky remain unknown at present, it is likely that they are still part of his belongings as he had intended to share them with one of us (AZ, personal communication). Finally, given the fact that molecular sequence data are now available for all cirrate genera and have successfully been used for phylogenetic inferences (Ziegler \& Sagorny, 2021), DNA barcoding of early cirrate life stage specimens would obviously be one of the most straightforward approaches to identify such material. However, this requires access to appropriately fixed or fresh tissue material as most historical cirrate museum specimens have presumably been fixed in formalin. In addition, DNA sampling requires use of tissues with relevant amounts of DNA, which might not be the case for the tough external egg capsule. However, direct access to the embryo, chorion, or external yolk sac still enclosed in an intact egg capsule necessitates the application of invasive techniques, which in theory should be avoided given the overall scarcity of early cirrate life stage specimens.

\section{Conclusions}

Due to the ongoing lack of deposited cirrate eggs suitable for detailed light or electron microscopical analysis, it remains impossible at present to provide a comprehensive description of the development of any given finned octopod species. While the combined data collected in previous as well as the present study provide sufficient information for outlining a generalized cirrate 
developmental series (although not sufficiently comprehensive to permit precise staging), von Boletzky's histological sections of cirrate embryos would certainly provide a significant boost for further inferences. Another topic for future studies would be to analyze the interaction between the spawning behavior of cirrate taxa and octocoral colonies in the deep-sea. Furthermore, yet unreported, additional early cirrate life stage material is likely to be present in natural history collections around the World, but first might require a positive identification-it is hoped that the present study can help to achieve this goal. However, as so clairvoyantly stated by Dr. Sigurd von Boletzky in the late 1970s, most aspects of cirrate development still represent a significant gap in our general understanding of the biology of extant cephalopods.

\section{Acknowledgements}

This article is dedicated to Sigurd von Boletzky, whose meticulous work and comprehensive knowledge on cephalopods have been and will always be an inspiration for cephalopod scholars. We are grateful to Owen Anderson and Sadie Mills (NIWA) as well as Daniel Geiger (SBMNH) for their hospitality and professional curatorial help. Francisco J. Cristobo, Frederick G. Hochberg, Timothy M. Shank, and Elizabeth K. Shea are thanked for generously granting access to previously unpublished specimen imagery. Additional information on cirrate material was kindly provided by Steve O'Shea. The manuscript was significantly improved by comments from Dirk Fuchs and one anonymous reviewer. Last but not least, we would like to express our gratitude to Dirk Fuchs for the invitation to contribute to the present volume and to Christian Klug for his endless editorial patience.

\section{Authors' contributions}

AZ conceived the study. AZ, AM, and NN performed experiments. AZ and AM analysed the data and wrote the manuscript. All authors read and approved the final manuscript.

\section{Funding}

Funding for this study was provided by the Deutsche Forschungsgemeinschaft (INST 217/849-1 FUGG). Open Access funding enabled and organized by Projekt DEAL.

\section{Availability of data and materials}

A MorphoBank project (\#4076) was created as repository for selected 3D data sets as well as additional imagery gathered in the course of this study (Ziegler et al., 2021).

\section{Author details}

${ }^{1}$ Institut für Evolutionsbiologie und Ökologie, Rheinische Friedrich-WilhelmsUniversität, An der Immenburg 1, 53121 Bonn, Germany. ${ }^{2}$ Institut für Klinische Radiologie, Universitätsklinikum Münster, Albert-Schweitzer-Campus 1, 48149 Münster, Germany.

Received: 19 September 2021 Accepted: 2 November 2021

Published online: 20 December 2021

\section{References}

Aldred, R. G., Nixon, M., \& Young, J. Z. (1983). Cirrothauma murrayi Chun, a finned octopod. Philosophical Transactions of the Royal Society London B, $301,1-54$

Berry, S. S. (1949). A new Opisthoteuthis from the Eastern Pacific. Leaflets in Malacology, 1, 23-26.

Berry, S. S. (1952). The flapjack devilfish, Opisthoteuthis, in California. California Fish and Game, 38, 183-188.
Boletzky, S. v. (1978-1979). Nos connaissances actuelles sur le développement des octopodes. Vie Milieu, 28-29, 85-120.

Boletzky, S. v. (1980). Note preliminaire sur quelques embryons d'octopodes cirromorphes (Mollusca, Cephalopoda). Haliotis, 10, 23.

Boletzky, S. v. (1982). On eggs and embryos of cirromorph octopods. Malacologia, 22, 197-204.

Boletzky, S. v. (1985). Céphalopodes. In L. Laubier \& C. Monniot (Eds.), Peuplements profonds du Golfe de Gascogne (pp. 401-408). Brest: IFREMER.

Boletzky, S. v. (1986). Encapsulation of cephalopod embryos: a search for functional correlations. American Malacological Bulletin, 4, 217-227.

Boletzky, S. v. (1989). Early ontogeny and evolution: the cephalopod model viewed from the point of developmental morphology. Geobios Mémoire Spécial, 12, 67-78.

Boletzky, S. v. (1998). Cephalopod eggs and egg masses. Oceanography and Marine Biology: An Annual Review, 36, 341-371.

Boletzky, S. v. (2002). Yolk sac morphology in cephalopod embryos. Abhandlungen der Geologischen Bundesanstalt, 57, 57-68.

Boletzky, S. v. (2003). Biology of early life stages in cephalopod molluscs. Advances in Marine Biology, 44, 143-203.

Boletzky, S. v. (2006). From head to foot - and back again: brachial crown development in the Coleoidea (Mollusca, Cephalopoda). Acta Universitatis Carolinae- Geologica, 49, 33-42.

Boletzky, S. v. (2009). Records of cephalopod eggs and embryos: what do we need? Bollettino Malacologico, 45, 39-42.

Boletzky, S. v. (2010). The "yolk organ" of cephalopod embryos: on transient functions from crawling substratum to provisional knapsack. Ferrantia, $59,14-21$.

Boletzky, S. v. (2012). Hatch-as-hatch-can: tricks of the trade in coleoid hatchlings (Mollusca: Cephalopoda). Neues Jahrbuch für Geologie und Paläontologie Abhandlungen, 266, 67-76.

Boyle, P. R., \& Daly, H. I. (2000). Fecundity and spawning in a deep-water cirromorph octopus. Marine Biology, 137, 317-324.

Collins, M. A. (2003). The genus Grimpoteuthis (Octopoda: Grimpoteuthidae) in the north-east Atlantic, with description of three new species. Zoological Journal of the Linnean Society, 139, 93-127.

Collins, M. A. (2004). Cryptoteuthis brevibracchiata: A new species and genus of cirrate octopod (Octopoda: Cirrata). Journal of Molluscan Studies, 70, 263-267.

Collins, M. A. (2005). Opisthoteuthis borealis: A new species of cirrate octopod from Greenland waters. Journal of the Marine Biological Association of the United Kingdom, 85, 1475-1479.

Collins, M. A., \& Henriques, C. (2000). A revision of the family Stauroteuthidae (Octopoda: Cirrata) with redescriptions of Stauroteuthis syrtensis and S. gilchristi. Journal of the Marine Biological Association of the United Kingdom, 80, 685-697.

Collins, M. A., Laptikhovsky, V., \& Strugnell, J. M. (2009). Expanded description of Opisthoteuthis hardyi based on new specimens from the Patagonian slope. Journal of the Marine Biological Association of the United Kingdom, $90,605-611$.

Collins, M. A., O'Dea, M., \& Henriques, C. (2001). A large Cirroteuthis magna (Cephalopoda: Cirroctopoda) caught on the Cape Verde Terrace (North Atlantic). Journal of the Marine Biological Association of the United Kingdom, $81,357-358$.

Collins, M. A., \& Villanueva, R. (2006). Taxonomy, ecology, and behaviour of the cirrate octopods. Oceanography and Marine Biology: An Annual Review, 44, 277-322.

Cuccu, D., Mereu, M., Cannas, R., Follesa, M. C., Cau, A., \& Jereb, P. (2009). Morphology, biology and molecular characterizations of Opisthoteuthis calypso (Cephalopoda: Octopoda) from the Sardinian Channel (central western Mediterranean). Journal of the Marine Biological Association of the United Kingdom, 89, 1709-1715.

Cupka, D.M. (1970). Observations on the biology and bathymetric distribution of the bathybenthic octopod Opisthoteuthis agassizi (Mollusca: Cephalopoda). M.Sc. thesis, The Florida State College of Arts and Sciences, 108 pp.

Daly, H. I., Boyle, P. R., \& Collins, M. A. (1998). Reproductive status of Opisthoteuthis sp. over an annual cycle. South African Journal of Marine Science, 20, 187-192.

Guerra, A., Villanueva, R., Nesis, K. N., \& Bedoya, J. (1998). Redescription of the deep-sea cirrate octopod Cirroteuthis magna Hoyle, 1885, and considerations on the genus Cirroteuthis (Mollusca: Cephalopoda). Bulletin of Marine Science, 63, 51-81. 
Hochberg, F. G., Nixon, M., \& Toll, R. B. (1992). Order Octopoda Leach, 1818. Smithsonian Contributions to Zoology, 513, 213-280.

Hochberg, F. G., Norman, M. D., \& Finn, J. K. (2014). Cirrate octopods. FAO Species Catalogue for Fishery Purposes, 4, 244-267.

Katugin, O.N., Yavnov, S.V., Shevtsov, G.A. (2010) Atlas of Cephalopod Mollusks of the Far Eastern Seas of Russia. TINRO-Centre, Vladivostok, $136 \mathrm{pp}$.

Knudsen, J., \& Roeleveld, M. A. C. (2002). J. T. Reinhardt and V. Prosch (1846): On Sciadephorus mülleri (Eschr.) - a translation into English. Bulletin of Marine Science, 71, 421-447.

Komi, R., Tsuchiya, K., Kodama, M., Takahama, Y., Masubuchi, K., Endo, S., Ishigami, M., Mimori, R., Nakamura, H., Nishikiori, K. (2018) The spawning and hatch of juvenile of the deep-sea cephalopod, Opisthoteuthis depressa. Book of Abstracts, Cephalopod International Advisory Council Conference 2018, St. Petersburg, Florida, USA, p. 189.

Kubodera, T., \& Okutani, T. (1986). New and rare cephalopods from the Antarctic waters. Memoirs of the National Institute of Polar Research, Special Issue, 44, 129-143.

Laptikhovsky, V. V. (1999). Fecundity and reproductive strategy of three species of octopods from the northwest Bering Sea. Russian Journal of Marine Biology, 25, 342-346.

Lipka, D.A. (1975) The systematics and zoogeography of cephalopods from the Gulf of Mexico. Ph.D. thesis, Texas A\&M University, 347 pp.

Lu, C. C. (2010). A new species of Opisthoteuthis, O. dongshaensis sp. nov., from the South China Sea (Octopoda: Cirrata: Opisthoteuthidae). Zoological Studies, 49, 405-420.

Meyer, W. T. (1906). Die Anatomie von Opisthoteuthis depressa (lijima und Ikeda). Zeitschrift für wissenschaftliche Zoologie, 85, 183-269.

Nesis, K. N. (1999). The duration of egg incubation in high-latitude and deepsea cephalopods. Russian Journal of Marine Biology, 25, 499-506.

Nesis, K. N. (2001). West-Arctic and East-Arctic distributional ranges of cephalopods. Sarsia, 86, 1-11.

O'Shea, S. (1999). The marine fauna of New Zealand: Octopoda (Mollusca: Cephalopoda). NIWA Biodiversity Memoir, 112, 1-280.

O'Shea, S., \& Lu, C. C. (2002). A new species of Luteuthis (Mollusca: CephaIopoda: Octopoda: Cirrata) from the South China Sea. Zoological Studies, 41,119-126.

Pardo-Gandarillas, M. C., Díaz-Santana-Iturrios, M., Fenwick, M., Villanueva, R., \& Ibánez, C. M. (2021). Redescription of the flapjack octopod Opisthoteuthis bruuni (Cephalopoda: Opisthoteuthidae), from the southeastern Pacific Ocean and evolutionary relationships of cirrate octopods. Malacologia, $63,155-169$.

Pereyra, W. Z. (1965). New records and observations on the flapjack devilfish, Opisthoteuthis californiana Berry. Pacific Science, 19, 427-441.

Piatkowski, U., \& Diekmann, R. (2005). A short note on the cephalopods sampled in the Angola Basin during the DIVA-1 expedition. Organisms, Diversity \& Evolution, 5, 227-230.

Piertney, S. B., Hudelot, C., Hochberg, F. G., \& Collins, M. A. (2003). Phylogenetic relationships among cirrate octopods (Mollusca: Cephalopoda) resolved using mitochondrial 165 ribosomal DNA sequences. Molecular Phylogenetics and Evolution, 27, 348-353.

Rauschert, M., \& Arntz, W. E. (2015). Antarctic Macrobenthos: A Field Guide of the Invertebrates Living at the Antarctic Seafloor. Arntz \& Rauschert Selbstverlag: Wurster Nordseeküste, 143 pp.

Reinhardt, J. T., \& Prosch, V. (1846). Om Sciadephorus mülleri (Eschr.), en undersögelse. Det Kongelige Danske Videnskabernes Selskabs Naturvidenskabelige Og Mathematiske Afhandlinger, 12, 187-224.

Robson, G. C. (1932). A monograph of the recent Cephalopoda based on the collections in the British Museum (Natural History). Part II. The Octopoda (excluding the Octopodinae). British Museum: London, $139 \mathrm{pp}$

Roper, C. F. E., \& Voss, G. L. (1983). Guidelines for taxonomic descriptions of cephalopod species. Memoirs of the National Museum Victoria, 44, 49-63.

Sanchez, P., \& Guerra, A. (1989). A new species of cirrate octopod Opisthoteuthis vossi from the southeast Atlantic (Cephalopoda: Octopoda). Bulletin of Marine Science, 44, 1159-1165.

Sartor, P., \& Belcari, P. (2009). Opisthoteuthis calypso (Cephalopoda: Octopoda) collected on bathyal bottoms of the northern Tyrrhenian Sea. Bollettino Malacologico, 45, 17-21.

Sasaki, M. (1929). A monograph of the dibranchiate cephalopods of the Japanese and adjacent waters. Journal of the College of Agriculture, Hokkaido Imperial University Sapporo, Supplement, 20, 1-357.
Schindelin, J., Arganda-Carreras, I., Frise, E., Kaynig, V., Longair, M., Pietzsch, T., Preibisch, S., Rueden, C., Saalfeld, S., Schmid, B., Tinevez, J. Y., White, D. J., Hartenstein, V., Eliceiri, K., Tomancak, P., \& Cardona, A. (2012). Fiji: An opensource platform for biological-image analysis. Nature Methods, 9, 676-682.

Shea, E. K., Ziegler, A., Faber, C., \& Shank, T. M. (2018). Dumbo octopod hatchling provides insight into early cirrate life cycle. Current Biology, 28, R144-R145.

Vecchione, M., Mangold, K.M., Young, R.E. (2016) Cirrata Grimpe, 1916. Finned octopods. The Tree of Life Web Project, http://tolweb.org/Cirrata/20086/ 2016.02.27

Vecchione, M. (2019). ROV observations on reproduction by deep-sea cephalopods in the central Pacific Ocean. Frontiers in Marine Science, 6, 403.

Vecchione, M., Piatkowski, U., \& Allcock, A. L. (1998). Biology of the cirrate octopod Grimpoteuthis glacialis (Cephalopoda; Opisthoteuthidae) in the South Shetland Islands, Antarctica. South African Journal of Marine Science, 20, 421-428.

Verrill, A. E. (1882). Report on the Cephalopods of the Northeastern Coast of America. Government Printing Office: Washington, D.C., 240 pp.

Verrill, A. E. (1885). Third catalogue of Mollusca recently added to the fauna of the New England coast and the adjacent parts of the Atlantic, consisting mostly of deep-sea species, with notes on others previously recorded. Transactions of the Connecticut Academy of Arts and Sciences, 6, 395-452.

Villanueva, R. (1992). Continous spawning in the cirrate octopods Opisthoteuthis agassizii and Opisthoteuthis vossi: features of sexual maturation defining a reproductive strategy in cephalopods. Marine Biology, 114, 265-275.

Villanueva, R., Collins, M. A., Sánchez, P., \& Voss, N. A. (2002). Systematics, distribution and biology of the cirrate octopods of the genus Opisthoteuthis (Mollusca, Cephalopoda) in the Atlantic Ocean, with description of two new species. Bulletin of Marine Science, 71, 933-985.

Voss, G. L. (1955). The Cephalopoda obtained by the Harvard-Havana expedition off the coast of Cuba in 1938-39. Bulletin of Marine Science of the Gulf and Caribbean, 5, 81-115.

Voss, G. L., \& Pearcy, W. G. (1990). Deep-water octopods (Mollusca; Cephalopoda) of the Northeastern Pacific. Proceedings of the California Academy of Sciences, 47, 47-94.

Werner, R., Hoernle, K., Hauff, F., Portnyagin, M., Yogodzinski, G., \& Ziegler, A. (2016). RV SONNE Fahrtbericht / Cruise Report SO 249 BERING - origin and evolution of the Bering Sea: an integrated geochronological, volcanological, petrological and geochemical approach. GEOMAR Report N. Ser., 30, 1-89.

Xavier, J. C., Allcock, A. L., Cherel, Y., Lipinski, M. R., Pierce, G. J., Rodhouse, P. G. K., Rosa, R., Shea, E. K., Strugnell, J. M., Vidal, E. A. G., Villanueva, R., \& Ziegler, A. (2015). Future challenges in cephalopod research. Journal of the Marine Biological Association of the United Kingdom, 95, 999-1015.

Ziegler, A. (2021) Die Dumbo-Oktopusse der Sieben Weltmeere. Naturwissenschaftliche Rundschau 12

Ziegler, A. (2018). Ein Dumbo-Baby aus dem Nordatlantik. GfBS Newsletter, 34, $32-35$.

Ziegler, A. (2019). Combined visualization of echinoderm hard and soft parts using contrast-enhanced micro-computed tomography. Zoosymposia, 15, 172-191.

Ziegler, A., Bock, C., Ketten, D. R., Mair, R. W., Mueller, S., Nagelmann, N., Pracht, E. D., \& Schröder, L. (2018). Digital three-dimensional imaging techniques provide new analytical pathways for malacological research. American Malacological Bulletin, 26, 248-273.

Ziegler, A., Kunth, M., Mueller, S., Bock, C., Pohmann, R., Schröder, L., Faber, C., \& Giribet, G. (2011). Application of magnetic resonance imaging in zoology. Zoomorphology, 130, 227-254.

Ziegler, A., \& Menze, B. H. (2013). Accelerated acquisition, visualization, and analysis of zoo-anatomical data. In J. Zander \& P. J. Mosterman (Eds.), Computation for Humanity: Information Technology to Advance Society (pp. 233-261). CRC Press.

Ziegler, A., \& Miller, A. (2022a). Cirroteuthidae Keferstein, 1866. In E. A. G. Vidal, E. Shea, \& H. Judkins (Eds.), Early-Life Stages of Cephalopods: An Identification Handbook. Springer.

Ziegler, A., \& Miller, A. (2022b). Grimpoteuthitidae O'Shea, 1999. In E. A. G. Vidal, E. Shea, \& H. Judkins (Eds.), Early-Life Stages of Cephalopods: An Identification Handbook. Springer.

Ziegler, A., \& Miller, A. (2022c). Cirroctopodidae Collins \& Villanueva, 2006. In E. A. G. Vidal, E. Shea, \& H. Judkins (Eds.), Early-Life Stages of Cephalopods: An Identification Handbook. Springer. 
Ziegler, A., \& Miller, A. (2022d). Opisthoteuthidae Verrill, 1896. In E. A. G. Vidal, E. Shea, \& H. Judkins (Eds.), Early-Life Stages of Cephalopods: An Identification Handbook. Springer.

Ziegler, A., \& Mueller, S. (2011). Analysis of freshly fixed and museum invertebrate specimens using high-resolution, high-throughput MRI. Methods in Molecular Biology, 771, 633-651.

Ziegler, A., \& Sagorny, C. (2021). Holistic description of new deep sea megafauna (Cephalopoda: Cirrata) using a minimally invasive approach. BMC Biology, 19, 81.
Ziegler, A., Miller, A., Nagelmann, N. (2021). Novel insights into early life stages of finned octopods (Octopoda: Cirrata). MorphoBank project \#4076. http://morphobank.org/permalink/?P4076.

\section{Publisher's Note}

Springer Nature remains neutral with regard to jurisdictional claims in published maps and institutional affiliations.
Submit your manuscript to a SpringerOpen ${ }^{\bullet}$ journal and benefit from:

- Convenient online submission

- Rigorous peer review

- Open access: articles freely available online

- High visibility within the field

- Retaining the copyright to your article

Submit your next manuscript at $\boldsymbol{\nabla}$ springeropen.com 